OPEN ACCESS

Edited by:

Hector J. Caruncho,

University of Victoria, Canada

Reviewed by:

Shota Nishitani,

University of Fukui, Japan

Raquel Romay-Tallon,

University of Illinois at Chicago,

United States

Carlos Spuch,

Instituto de Investigación Sanitaria

Galicia Sur (IISGS), Spain

${ }^{*}$ Correspondence: Marin Veldic

Veldic.Marin@mayo.edu

Specialty section: This article was submitted to

Neuropharmacology,

a section of the journal

Frontiers in Pharmacology

Received: 03 January 2020

Accepted: 25 March 2020

Published: 22 April 2020

Citation:

Gardea-Resendez M, Kucuker MU, Blacker CJ, Ho AM-C, Croarkin PE,

Frye MA and Veldic M (2020)

Dissecting the Epigenetic Changes

Induced by Non-Antipsychotic

Mood Stabilizers on Schizophrenia

and Affective Disorders:

A Systematic Review.

Front. Pharmacol. 11:467.

doi: 10.3389/fphar.2020.00467

\section{Dissecting the Epigenetic Changes Induced by Non-Antipsychotic Mood Stabilizers on Schizophrenia and Affective Disorders: A Systematic Review}

\author{
Manuel Gardea-Resendez ${ }^{1}$, Mehmet Utku Kucuker ${ }^{2}$, Caren J. Blacker ${ }^{2}$, Ada M.-C. Ho ${ }^{2}$, \\ Paul E. Croarkin ${ }^{2}$, Mark A. Frye ${ }^{2}$ and Marin Veldic ${ }^{2 *}$
}

${ }^{1}$ Department of Psychiatry, Universidad Autónoma de Nuevo León, Monterrey, México, ${ }^{2}$ Department of Psychiatry and
Psychology, Mayo Clinic Depression Center, Mayo Clinic, Rochester, MN, United States

Background: Epimutations secondary to gene-environment interactions have a key role in the pathophysiology of major psychiatric disorders. In vivo and in vitro evidence suggest that mood stabilizers can potentially reverse epigenetic deregulations found in patients with schizophrenia or mood disorders through mechanisms that are not yet fully understood. However, their activity on epigenetic processes has made them a research target for therapeutic approaches.

Methods: We conducted a comprehensive literature search of PubMed and EMBASE for studies investigating the specific epigenetic changes induced by non-antipsychotic mood stabilizers (valproate, lithium, lamotrigine, and carbamazepine) in animal models, human cell lines, or patients with schizophrenia, bipolar disorder, or major depressive disorder. Each paper was reviewed for the nature of research, the species and tissue examined, sample size, mood stabilizer, targeted gene, epigenetic changes found, and associated psychiatric disorder. Every article was appraised for quality using a modified published process and those who met a quality score of moderate or high were included.

Results: A total of 2,429 records were identified; 1,956 records remained after duplicates were removed and were screened via title, abstract and keywords; 129 records were selected for full-text screening and a remaining of 38 articles were included in the qualitative synthesis. Valproate and lithium were found to induce broader epigenetic changes through different mechanisms, mainly DNA demethylation and histones acetylation. There was less literature and hence smaller effects attributable to lamotrigine and carbamazepine could be associated overall with the small number of studies on these agents. Findings were congruent across sample types.

Conclusions: An advanced understanding of the specific epigenetic changes induced by classic mood stabilizers in patients with major psychiatric disorders will facilitate 
personalized interventions. Further related drug discovery should target the induction of selective chromatin remodeling and gene-specific expression effects.

Keywords: epigenetics, mood disorders, schizophrenia, lithium carbonate, valproic acid, anticonvulsants, histone deacetylase inhibitors, DNA methylation

\section{INTRODUCTION}

\section{Rationale}

Psychiatric illness entails a severe disease burden that is associated with reduced productivity, quality of life, and life expectancy (Vigo et al., 2016). Globally, bipolar disorder (BD), major depressive disorder (MDD), and schizophrenia (SCZ) affect $>1 \%, 6 \%$, and $\approx 1 \%$ of the population, respectively (Malhi and Mann, 2018; Vieta et al., 2018; Marder and Cannon, 2019). Differentiation between these three major psychiatric diseases disorders is typically based on symptoms and course patterns. However, overlapping foundations, heterogeneous clinical features, and common underlying genetic vulnerabilities challenge traditional definitions of related nosological boundaries (Cross-Disorder Group of the Psychiatric Genomics, 2013; Cheng et al., 2018). The pleiotropic nature and the influence of gene-environment interactions on pathophysiology has focused attention towards a more comprehensive understanding of psychiatric illness and a pharmacogenomics approach of existing treatment strategies (Lopez-Leon et al., 2008; Serretti and Mandelli, 2008; Gatt et al., 2015; Harrison, 2015).

Epigenetic changes involve reversible chromatin rearrangements that induce mitotically heritable, stable, long-term, and reversible gene expression patterns without altering the DNA sequence (Figure 1) (Bernstein et al., 2010; Allis and Jenuwein, 2016). DNA methylation and histone modifications are the most studied epigenetic marks in physiological and pathological contexts (Schenkel et al., 2017). In DNA methylation, DNA methyltransferases (DNMT) transfer a methyl group to $5^{\prime}$ cytosine residues at cytosine-guanine sequences $(\mathrm{CpG})$ which are clustered in $\mathrm{CpG}$ islands, often unmethylated and located within gene promoters of active transcription and tumor suppressor genes (Inbar-Feigenberg et al., 2013; Houtepen et al., 2016). Acetylation and deacetylation of histones through histone deacetylases

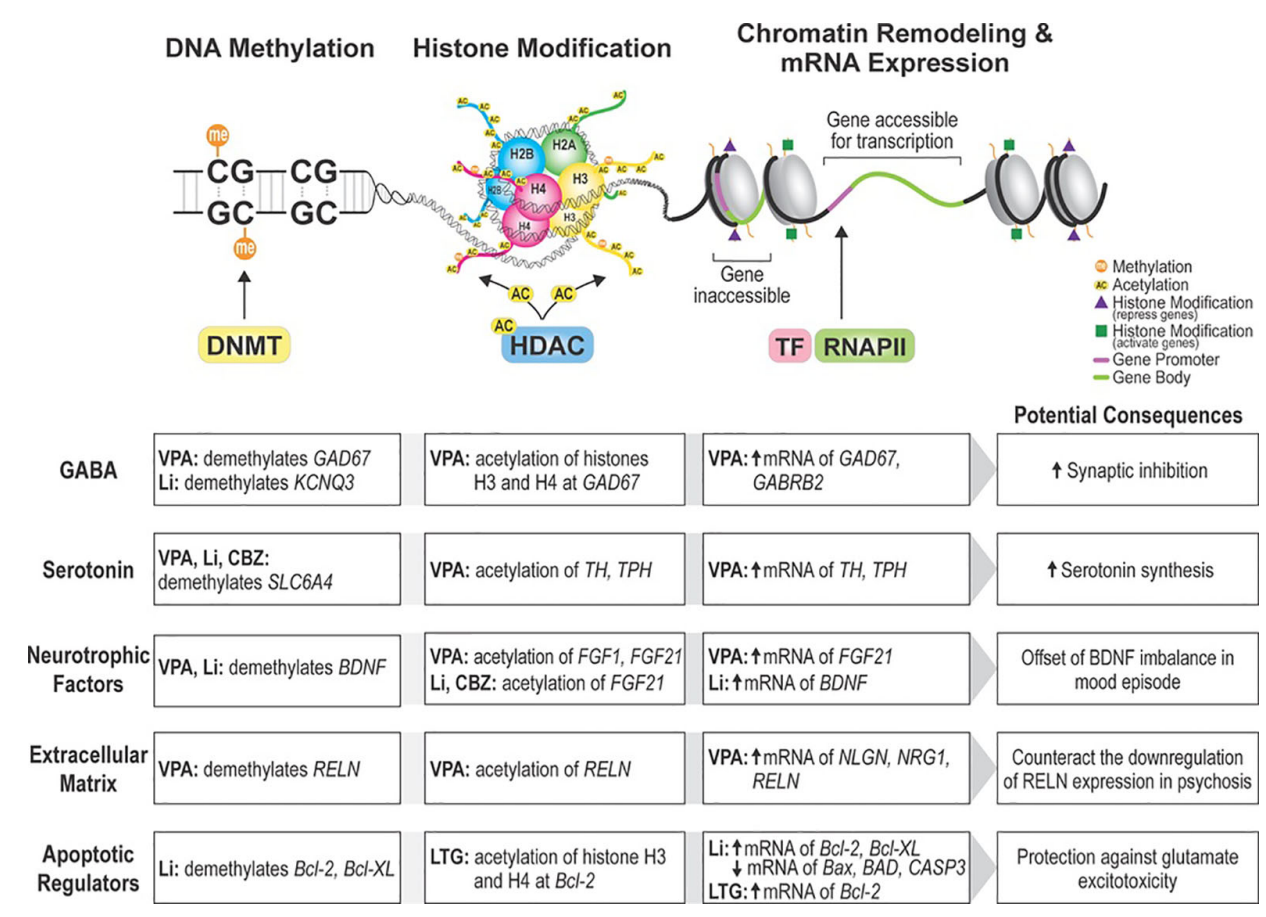

FIGURE 1 | Pathways epigenetically impacted by mood stabilizers. Non-antipsychotic mood stabilizers alter the epigenetic expression of a variety of candidate genes in bipolar disorder and schizophrenia. Findings from our systematic review suggest that epigenetic changes induced by mood stabilizers produce neuroprotective effects through different pathways. DNMT, DNA methyltransferase; HDAC, histone deacetylase; TF, transcription factor; RNAPII, RNA polymerase II; VPA, valproic acid; Li, lithium; CBZ, carbamazepine; LTG, lamotrigine; GAD67, glutamate decarboxylase 67; KCNQ3, potassium voltage-gated channel subfamily Q member 3; GABRB2, gamma-aminobutyric acid receptor subunit beta-2; SLC6A4, sodium-dependent serotonin transporter and solute carrier family 6 member 4; $\mathrm{TH}$, tyrosine hydroxylase; TPH, tryptophan hydroxylase; FGF21, fibroblast growth factor 21; BDNF, brain-derived neurotrophic factor; RELN, reelin; NLGN, neuroligin; NRG1, neuregulin 1; Bcl-2, Bcl-2 apoptotic regulator Bcl-XL- BCL2 Like 1; Bax, BCL2 associated X, apoptosis regulator; BAD, BCL2 associated agonist of cell death; CASP3, caspase 3. 
(HDACs) and histone acetyltransferases (HATs) activity regulate chromatin structure and gene expression (Eyal et al., 2004; Machado-Vieira et al., 2011; Inbar-Feigenberg et al., 2013; Schenkel et al., 2017). Whilst increased histone acetylation and decreased DNA methylation are associated with active transcription and gene expression, histone deacetylation and DNA hypermethylation are indicators of heterochromatin (condensed state of chromatin) and gene silencing (Machado-Vieira et al., 2011; Inbar-Feigenberg et al., 2013). Similarly, some studies on epigenetic modifications are based on the hypotheses that abnormal RNA expression is linked with altered epigenetics at gene promoter regions and regulatory sequences (Houston et al., 2013).

In physiological circumstances, epigenetic mechanisms control neurobiological processes but deregulation in these mechanisms can translate into an increased risk of disease development (Bernstein et al., 2010; Davies et al., 2012). Epimutations secondary to gene-environment interactions have been described to have a key role in the pathophysiology of major psychiatric disorders (Abdolmaleky et al., 2019) where aberrant DNA methylation and histone modification patterns have been identified. Histone acetylation levels are significantly altered in individuals with $\mathrm{BD}$ and, to a lesser extent, in individuals with SCZ (Gavin and Sharma, 2010; Machado-Vieira et al., 2011).There is also a reduction in global and specific DNA methylation levels in individuals with $\mathrm{BD}, \mathrm{MDD}$, and SCZ (Alladi et al., 2018). In vitro and in vivo studies have suggested the potential of mood stabilizers to reverse epimutations in major psychiatric disorders (Pisanu et al., 2018) making them a target for further research.

Classic mood stabilizers comprising of lithium, valproate, lamotrigine, and carbamazepine, which show antimanic, antidepressant and prophylactic effects, have been characterized as the mainstay of treatment for BD and as aides in MDD and SCZ (Bauer and Mitchner, 2004; Goodwin and Malhi, 2007). While mechanisms of action of valproic acid (VPA), carbamazepine (CBZ), lamotrigine (LTG), and lithium (Li) are not completely understood, there is robust evidence on their ability to target altered epigenetic functions (Seo et al., 2014; Houtepen et al., 2016; Pisanu et al., 2018) involved in the pathophysiology of BD, MDD and SCZ (Higuchi et al., 2011; Ludwig and Dwivedi, 2016). The putative neuroprotective and neurotrophic actions of $\mathrm{Li}$ are thought to be induced through epigenetic mechanisms that enhance the expression of molecules involved in neuroplasticity and cytoprotective proteins (Chuang et al., 2002; Schloesser et al., 2012). Likewise, identification of VPA as a class I and IIa HDAC inhibitor (Gottlicher et al., 2001; Phiel et al., 2001) suggests that associated reversion of HDACdependent transcriptional repression and histone hyperacetylation could be involved in its mood-stabilizing properties (Gavin and Sharma, 2010; Machado-Vieira et al., 2011). Less studied are the mechanisms of action of LTG and CBZ; neuroprotective effects of LTG exerted through upregulation of excitatory amino acid transporter activity (Schloesser et al., 2012; Leng et al., 2013) and increased global DNA methylation induced by CBZ (Pisanu et al., 2018) are the best described epigenetic changes. The histone deacetylase inhibitory properties of anticonvulsants (Eyal et al., 2004) and the potent antioxidant effects of lithium (Leng et al., 2008; Dwivedi and Zhang, 2015) have been postulated as potential pathways to reverse dysfunctional epigenetic regulation and variability in treatment response (Machado-Vieira et al., 2011).

\section{Objectives and Research Question}

Studies on the epigenetic impact on candidate genes of mood stabilizers, especially Li and VPA, have consistently increased in the past decade but attempts to summarize the findings have been scarce (Alladi et al., 2018; Pisanu et al., 2018). This systematic review provides a qualitative summary of the current state of knowledge of the epigenetic effects of nonantipsychotic mood stabilizers in MDD, BD, and SCZ in an attempt to define the specific mechanisms through which these agents act at the epigenomic level.

\section{METHODS}

\section{Study Design}

We developed the systematic review protocol based on the Preferred Reporting Items for Systematic Review and MetaAnalysis Protocols (PRISMA-P) 2015 (Shamseer et al., 2015) and conducted a comprehensive literature search of PubMed and EMBASE from their inception through 30 September 2019.

\section{Search Strategy}

The following search string was used: "epigenetic" OR "epigenomic" OR "DNA methylation" OR "DNA hydroxymethylation" OR "histone acetylation" OR "histone deacetylation" OR "histone methylation") AND ("lithium" OR "carbamazepine" OR "lamotrigine" OR "mood stabilizer" OR "valproic acid”) NOT “cancer”. Search strategy for valproic acid was narrowed using the Boolean operator NOT, to exclude studies related to use of VPA as an epigenetic cancer drug.

Articles were collated in Rayaan QCRI (Ouzzani et al., 2016). Duplicates were eliminated by the software. Each abstract was reviewed, through a blinded process, for eligibility by two independent reviewers (M.G.R. and M.U.K.). Disagreements were resolved via discussion and a senior reviewer (M. V.) assessing the relevance of the selected data. A total of 129 articles were selected for full-text review (Figure 2).

\section{Participants, Interventions, Comparators}

Literature eligible for inclusion were (a) published articles with original data in English; (b) about gene-specific studies with patients, human-tissue, or mammalian models involving assessment of epigenetic changes with use of lithium, divalproex, carbamazepine, or lamotrigine for major psychiatric disorders (psychotic disorders, bipolar disorder, and depression) that (c) met a minimum quality standard of moderate or higher. The three selected major psychiatric disorders were chosen due to phenotypic similarities and shared symptomatology. Exclusion criteria were (a) reviews or non-experimental papers, (b) papers that did not report specific 


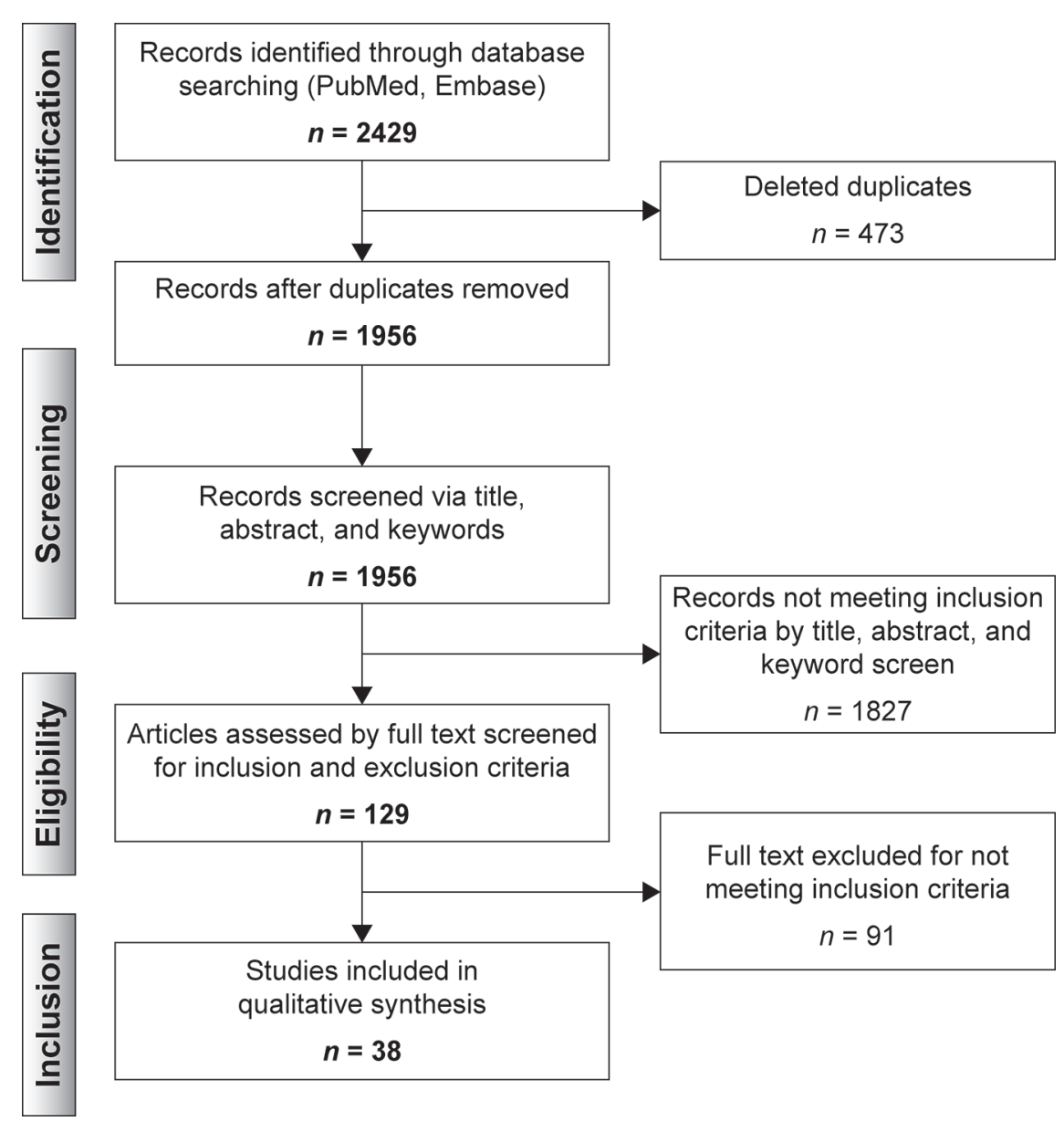

FIGURE 2 | Flowchart based on PRISMA.

epigenetic changes, (c) papers not focused on the aforementioned psychiatric disorders, or (d) literature only published as abstracts or conference summaries.

\section{Data Sources, Studies Sections and Data Extraction}

Each paper was reviewed for the nature of research, the species and tissue examined, sample size, mood stabilizer, targeted gene, epigenetic changes found, and associated psychiatric disorder.

\section{RESULTS}

\section{Study Selection and Characteristics}

Thirty-eight articles met all the inclusion criteria; studies retrieved for the review were organized in a flow diagram (Figure 2). Twenty-one described studies of rodent samples (Tremolizzo et al., 2002; Dong et al., 2005; Tremolizzo et al., 2005; Kim et al., 2008; Dong et al., 2010; Hobara et al., 2010; Perisic et al., 2010; Matrisciano et al., 2011; Wang et al., 2012;
Zimmermann et al., 2012; Calabrese et al., 2013; Leng et al., 2013; Ookubo et al., 2013; Liu et al., 2014; Mackowiak et al., 2014; Balasubramanian et al., 2015; Bator et al., 2015; Dwivedi and Zhang, 2015; Lee et al., 2015; Leng et al., 2016; Bahna and Niles, 2017). Seven articles studied human cell lines (Asai et al., 2013; Kao et al., 2013; Dyrvig et al., 2017; Zong et al., 2017; Billingsley et al., 2018; Dyrvig et al., 2019; Manca et al., 2019) and eight focused on blood samples of subjects diagnosed with either of the selected psychiatric disorders (Gavin et al., 2009; D’Addario et al., 2012; Dell'Osso et al., 2014; Huzayyin et al., 2014; Burghardt et al., 2015; Burghardt et al., 2016; Houtepen et al., 2016; Bengesser et al., 2018). One article studied rodents and human cell lines and subjects (Kaminsky et al., 2015) and one focused on patients and human cell lines (Kakiuchi et al., 2003). The papers are summarized in Tables 1-4.

\section{Synthesized Findings Rodent Models}

SCZ-like epigenetic modifications and symptoms, namely positive, negative, and cognitive, have been replicated in 
TABLE 1 | Summaries of animal studies included in the systematic analysis.

\begin{tabular}{|c|c|c|c|c|}
\hline $\begin{array}{l}\text { Reference } \\
\text { (by year) }\end{array}$ & Nature of research & $\begin{array}{l}\text { Species, } \\
\text { tissue }\end{array}$ & $\begin{array}{c}\text { Mood } \\
\text { stabilizer }\end{array}$ & \\
\hline $\begin{array}{l}\text { (Bahna and Niles, } \\
\text { 2017) }\end{array}$ & $\begin{array}{l}\text { Examine mechanisms underlying the } \\
\text { upregulation of melatonin MT1 receptors by } \\
\text { VPA. }\end{array}$ & $\begin{array}{l}\text { Rat, glioma } \\
\text { cells }\end{array}$ & VPA & MT \\
\hline (Leng et al., 2016) & $\begin{array}{l}\text { To investigate the association between FGF21 } \\
\text { expression and mood stabilizer's histone } \\
\text { deacetylase inhibition in glial cells as well as to } \\
\text { identify the HDAC isoform(s) involved in the } \\
\text { process. }\end{array}$ & $\begin{array}{l}\text { Rat, glioma } \\
\text { cells and } \\
\text { cortical glial } \\
\text { cells }\end{array}$ & $\begin{array}{l}\text { VPA, Li, } \\
\text { LTG, CBZ }\end{array}$ & FGF \\
\hline $\begin{array}{l}\text { (Bator et al., } \\
\text { 2015) }\end{array}$ & $\begin{array}{l}\text { Explore the effect of VPA on histone } \\
\text { acetylation in a neurodevelopmental animal } \\
\text { model of schizophrenia. }\end{array}$ & $\begin{array}{l}\text { Rat; adult } \\
\text { medial } \\
\text { prefrontal } \\
\text { cortex tissue }\end{array}$ & VPA & $\begin{array}{l}\mathrm{H} 3 \mathrm{Kg} \\
\mathrm{HDAC}\end{array}$ \\
\hline $\begin{array}{l}\text { (Balasubramanian } \\
\text { et al., 2015) }\end{array}$ & $\begin{array}{l}\text { Evaluate the potential epigenetic effects of } \\
\text { mood stabilizers on the expression of the } \\
\mathrm{BH} 4 \text { pathway gene Spr }\end{array}$ & $\begin{array}{l}\text { Rat, } \\
\text { serotoninergic } \\
\text { cell line } \\
\text { (RN46A) }\end{array}$ & $\begin{array}{l}\text { VPA, LTG, } \\
\text { CBZ, and Li }\end{array}$ & Spr \\
\hline
\end{tabular}

(Lee et al., 2015) To identify genes affected by Li and VPA and assess the epigenetic mechanisms involved in their mechanism of action. Determine whether chronic exposure to Li and VPA could induce histone modifications in the Lepr promoter.

(Dwivedi and Aimed to delineate Li's epigenetic impact on Zhang, 2015) the expression of BDNF gene and other pro and anti-apoptotic genes.
Rat,

hippocampal

tissue

Rat, hippocampal neurons
VPA, Li Lepr

Li
(Liu et al., 2014) Investigate the hypothetical interrelation between histone acetylation modification and expression of TH and TPH gene in CUSinduced depression in rats.
(Mackowiak et al., Investigate the epigenetic processes in a 2014)

(Ookubo et al., 2013)

neurodevelopmental model of SCZ based on the gestational administration of MAM. An additional pharmacological study was performed to determine the period in adolescence critical for developing dysfunction in histone $\mathrm{H} 3$ methylation in the adult offspring.

(Leng et al., 2013) To investigate the neuroprotective effects of LTG exerted via chromatin remodeling through HDAC inhibition and up-regulation of $\mathrm{BCl}-2$.

Determine similar region-specific effects on tissue monoamine concentrations or protein expression of $\mathrm{AcH} 3$ and HDACs with antidepressants and mood stabilizers and identify the relation of HDAC and specific antidepressant-like effects in brain regions.
Rat, hippocampal tissue

Rat, medial VPA prefrontal cortex

Rat, cerebellar LTG granule cells

Mouse, brain $\begin{array}{ll}\text { VPA, Li, } & \text { AcH3, } \\ \text { CBZ and } & \text { HDACs } \\ \text { LTG } & \end{array}$ and $\mathrm{H} 4$, $\mathrm{BCl}-2$
H3K4me3, ASH2L, JARID1C
Data extracted

VPA induces an upregulation of the MT1 receptor through a mechanism involving histone $\mathrm{H} 3$ acetylation on the MT1 promoter. In C6 cells VPA significantly increased (up to 35-fold) levels of FGF21 mRNA in a dose- and time-related manner. Li induced a weak (2- to 3-fold) increase in FGF21 mRNA levels at high concentrations. LTG and CBZ were ineffective. VPA and, less significantly, LTG increased acetylation of histone 3 levels. CBZ produced a modest dose-dependent increase, while Li did not produce significant changes.

In primary glia VPA dose-dependently increased FGF21 mRNA levels.

VPA administration did not affect the decrease in H3K9ac nor acetylation level of H3K9 but prevented the MAM induced increase in HDAC2 immunoreactivity at P70.

VPA and Li increased Spr mRNA expression. VPA also increased intracellular $\mathrm{BH} 4$ levels and acetylation at K3K9/K14ac histone mark in the Spr promoter region.

CBZ and LTG did not result in any significant change in mRNA expression.

Increased Lepr expression with Li (32.6\%) and VPA (127.4\%).

Both drugs produced histone $\mathrm{H} 3$ methylation and acetylation in Lepr.

$B D N F, B A X$, Li produced a dose-dependent increase in mRNA $B C l-2, B C l-\quad$ expression of $B D N F$ and exon IV, while methylation $\mathrm{XI}, \mathrm{BAD}, \quad$ was decreased in exon IV.

CASP-3 Expression of anti-apoptotic genes $\mathrm{BCl}-2$ and $\mathrm{BCl}-\mathrm{XI}$ was increased while expression of pro-apoptotic genes $B a x, B A D$, and caspase 3 was decreased with Li exposure.

$\mathrm{TH}, \mathrm{TPH} \quad$ VPA prevented a decrease of $\mathrm{H} 3$ and $\mathrm{H} 4$ acetylation and an increase of HDAC5 protein expression in CUS rats.

VPA clearly inhibited decrease of $\mathrm{TH}$ protein and mRNA expression but only partly reversed the decrease of TPH protein and mRNA expression. VPA decreased JARID1c protein levels. Early exposure to VPA prevented the expected decrease in $\mathrm{H} 3 \mathrm{~K} 4 \mathrm{me} 3$ and $A S H 2 L$ protein induced by MAM but did not affect the JARID1c levels.
Histones H3 LTG produced a time-dependent increase in the acetylation levels of histones $\mathrm{H} 3$ and induced a moderate decrease in HDAC activity. LTG induced a dose-dependent increment of $\mathrm{BCl}-2$ mRNA and protein levels.

$\mathrm{AcH} 3$ protein expression was significantly increased with VPA, Li, and LTG in cingulate cortex and nucleus accumbens; no effect was observed with CBZ and LTG in amygdala. In striatum, expression of HDAC-2, -3 , and -8 was increased with $\mathrm{CBZ}$ and LTG while Li induced decreases of HDAC-1, -3, -4, $-5,-7,-8$, and -10 . HDAC-2 and -3 were increased in nucleus accumbens after exposure to CBZ and 
TABLE 1 | Continued

\begin{tabular}{lcccc}
\hline $\begin{array}{l}\text { Reference } \\
\text { (by year) }\end{array}$ & Nature of research & $\begin{array}{c}\text { Species, } \\
\text { tissue }\end{array}$ & $\begin{array}{c}\text { Mood } \\
\text { stabilizer }\end{array}$ & $\begin{array}{c}\text { Targeted } \\
\text { gene }\end{array}$ \\
\hline
\end{tabular}

LTG. In hippocampus, VPA, Li, and LTG decreased expression of HDAC-5 and -7. In cingulate, VPA, CBZ, and LTG increased HDAC-1, HDAC-3, and HDAC-5 protein expression. The former two were

(Calabrese et al., 2013)

Explore the neuroadaptive changes produced by chronic single or combinatory therapy with lurasidone and VPA.
Rat, ventral, and dorsal hippocampal tissue
VPA alone

or in combinat with lurasidone
(Wang et al., 2012)

(Zimmermann

et al., 2012) 2011)

(Hobara et al. 2010)

(Dong et al. 2010)

(Perisic et al., 2010)
Investigate the effect of VPA on the mRNA levels of two excitatory post-synaptic cell adhesion molecules and two extracellular matrices in primary astrocyte cultures.

Explore the inhibitory effects of antidepressants, VPA and CBZ on DNMT activity in primary astrocytes from rat cortex.

mGlu2/3 receptors on the epigenetic

regulation of genes linked to the

pathophysiology of schizophrenia.

To investigate the effect of antidepressants and mood stabilizers on the mRNA levels of HDACs in mouse leukocytes.

To explore if the demethylation of RELN and Gad67 promoters induced by VPA is the result of induction of DNA demethylation mechanisms or reduced DNMT activity. Analyze the potential of mood stabilizers to affect epigenetic parameters in astrocytes by measuring global histone $\mathrm{H} 3$ and $\mathrm{H} 4$ acetylation/methylation, DNA methylation and GLT-1 promoter.
Rat, neuronal, VPA astroglial, and neuro-glia mixed culture systems

Rat, primary astrocytes

Mouse, brain

VPA and CBZ

VPA

Mouse, leukocytes

Mouse, frontal VPA cortex

Rat, primary astrocytes from hippocampus and cortex also increased by CBZ and LTG in amygdala. $B D N F$, Arc, In ventral hippocampus, VPA increased the long $3^{\prime}$ and HDAC- UTR BDNF mRNA levels and more robustly in combination with lurasidone. Expression levels of exon IV was increased with VPA alone and in combination but mRNA levels of exon IV were reduced with VPA alone.

In dorsal hippocampus, VPA, alone and in combination, increased total BDNF mRNA levels. VPA significantly increased proBDNF and mature BDNF levels in this sub region. VPA alone and in combination upregulated mRNA levels of Arc in hippocampus.

The gene expression of HDACs, mainly HDAC-2 and -5 , was modified with the combinatory therapy. NLGN, $\quad$ VPA increased levels of NLGN, NRG1, NPTX1, and NRG1, TSP- TSP-3 mRNA in a time- and concentration3 , and dependent manner in astrocytes.

NPTX1

DNMT

Neither VPA nor CBZ decreased DNMT activity in astrocytes.

Gadd45-B Exposure to VPA produced a 2- to 3-fold increase of Gadd45-B mRNA brain levels. VPA increased the binding of Gadd45- $B$ to reelin, GAD67 and BDNF-IX promoters.

$\mathrm{Li}$ and VPA HDAC-2, -4, The expression of HDAC2. HDAC4, HDAC5, $-5,-6$, and HDAC6, and HDAC8 mRNA of mice receiving either -8 mRNA Li or VPA were comparable to those of control mice. GAD67 and VPA failed to induce significant changes in DNMT1 RELN, and DNMT3a mRNA levels but produced DNA DNMT1 and demethylation activity as well as an upregulation of DNMT3a RELN and GAD67 mRNA expression.

Global Only VPA induced global histone $\mathrm{H} 3$ and $\mathrm{H} 4$ histone transient hyperacetylation and significant acetylation demethylation. LTG did not produce changes of DNA and DNA methylation.

methylation, VPA did not change DNMT-1 levels in astrocytes and GLT-1 slightly reduced levels of dimethyl-H3K9.

Exposure to CBZ did not inhibited class I or class II HDACs.

VPA increased GLT-1 mRNA in a dose dependent manner, while LTG did not influence GLT-1 mRNA expression.

(Kim et al., 2008) Examine expression of melatonin MT1 receptor and selected epigenetic modulators after exposure to clinically relevant concentrations of VPA.

(Tremolizzo et al., Study if VPA-induced hyperacetylation of 2005) chromatin histone tails can prevent hypermethylation of reelin promoter and schizophrenia-like behavioral traits induced by methionine in mice.

(Dong et al., To test if pretreatment with VPA revert the downregulation of RELN and GAD67 expression induced by MET and the

Rat, glioma VPA

cells

MT1

receptor,

MeCP2, Significant time-dependent increases in mRNA

HDAC-1, -2,

and -3

Mouse, frontal VPA RELN

cortex

VPA induced an increase of acetylated $\mathrm{H} 3$ in frontal cortex and prevented $\mathrm{H} 3$ hypermethylation. VPA reversed the methionine-induced hypermethylation from the reelin promoter region and prevented reelin mRNA downregulation.

Mouse, frontal VPA cortex
GAD67 and VPA increased levels of acetylated-H3 flanking RELN RELN and GAD67 promoter sites and upregulated the 
TABLE 1 | Continued

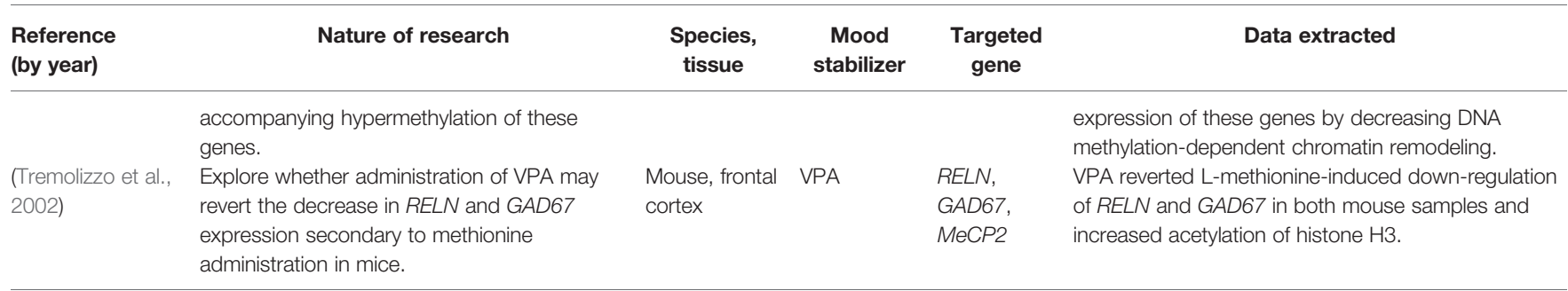

M1, Metallothionein-1M; VPA, valproic acid; Li, lithium; FGF21, fibroblast growth factor 21; LTG, lamotrigine; CBZ, carbamazepine; MAM, methylazoxymethanol acetate; DNMT, DNA methyltransferases; HDACs, histone deacetylases.

animal samples through the administration of L-methionine (MET) and methylazoxymethanol acetate (MAM) to obtain models for SCZ. Both VPA and antipsychotics have shown a potential reversibility effect of symptoms and epigenetic markers on MET or MAM treated rodents (Tremolizzo et al., 2002; Lodge, 2013; Wang et al., 2015).

Five papers examined the impact of mood stabilizers on genes involved in the regulation of histone activity (Kim et al., 2008; Hobara et al., 2010; Ookubo et al., 2013; Mackowiak et al., 2014; Bator et al., 2015). Kim et al. (Kim et al., 2008) exposed rat C6 glioma cells to prolonged treatment with low clinically relevant doses of VPA $(0.5 \mathrm{mM}$ or $1 \mathrm{mM})$, reporting significant increases in HDAC-1, -2 , and -3 mRNA expression (class I HDAC isoforms), as well as increases in methyl-CpG binding protein $2(\mathrm{MeCP})$ and Metallothionein-1M ( $\left.\mathrm{MT}_{1}\right)$ mRNA expression. These findings suggest a compensatory temporal upregulation following the HDAC inhibitory effects of VPA as well as a relation between HDACs involvement in the melatonin $\mathrm{MT}_{1}$ receptor induction. Similarly, Hobara et al. (2010) investigated the effect of Li and VPA in class I and II HDACs (HDAC-2, -4, $-5,-6$, and -8 ) in lymphocytes from male C57BL/6 and BALB/c mice exposed to a forced swim test, a highly reliable model of depressive-like behavior (Yankelevitch-Yahav et al., 2015). After 21 days of treatment, expression of HDAC-2, -4, -5, -6, and -8 mRNA levels were comparable to those of stress-free control mice, suggesting a non-selective nature of Li and VPA as HDAC inhibitors, and that they do not have a causal role in the altered expression of HDACs in mood disorder patients (Hobara et al., 2010). The region-specific changes in histone deacetylase expression and histone $\mathrm{H} 3$ acetylation $(\mathrm{AcH} 3)$ induced by VPA, Li, CBZ, and LTG in C57BL/6 mice was investigated in another study (Ookubo et al., 2013). Treatment with VPA, Li, and LTG significantly increased AcH3 expression in nucleus accumbens and cingulate cortex, while CBZ and LTG increased HDAC-2 and -3 in striatum; VPA, CBZ, and LTG increased HDAC-3 in cingulate cortex and HDAC-5 in the amygdala (Ookubo et al., 2013). The latter shows epigenetic changes associated with modified HDAC expression and that transcriptional activation includes an alternating recruitment of histone acetyltransferases and HDACs, rather than a process of increasing acetylation only (Shahbazian and Grunstein, 2007). Impact on histone $\mathrm{H} 3$ methylation in the prefrontal cortex was studied in MAM-injected Wistar male rats through measurements of ASH2L levels, which encodes for Set1/Ash2 histone methyltransferase complex subunit ASH2, and lysinespecific demethylase 5C enzyme, JARID1c (Mackowiak et al., 2014). Use of VPA in early adolescence prevented disturbances in $A S H 2 L$ and $\mathrm{H} 3 \mathrm{~K} 4 \mathrm{me} 3$ but did not affect the levels of JARID1c, a key protein in the demethylase activity on $\mathrm{H} 3 \mathrm{~K} 4 \mathrm{me} 3$ (Mackowiak et al., 2014; Rondinelli et al., 2015). The same group reported that VPA prevented an increase in HDAC-2 levels evoked by MAM but not H3K9 acetylation levels (Bator et al., 2015). An additional paper studied the impact of CBZ and VPA on DNMT1 activity in primary astrocytes from rat cortex, reporting that neither of the agents altered the expression levels of DNMT (Zimmermann et al., 2012).

Chronic unpredictable stress (CUS)-induced depression in rats was used in a study of epigenetic histone modification and gene expression induced by VPA on tyrosine hydroxylase $(\mathrm{TH})$ and tryptophan hydroxylase $(T P H)$, enzymes involved in the biosynthesis of L-DOPA (a precursor to norepinephrine) and serotonin respectively (Liu et al., 2014). In controls, CUS led to decreased acetylation of $\mathrm{H} 3 \mathrm{~K} 9$ and $\mathrm{H} 4 \mathrm{~K} 12$, and reduced expression of $\mathrm{TH}$ and $\mathrm{TPH}$. Administration of VPA reversed these downregulations and prevented an increase of HDAC-5 in the hippocampus. Regulation of another gene involved in the monoamine neurotransmitter formation, Spr, associated with increased susceptibility to mood disorders, was studied by evaluating the epigenetic changes after exposure to VPA, Li, LTG, and CBZ (Balasubramanian et al., 2015). Exposing RN46A cells (derived from embryonic rat medullary raphe nucleus) to VPA and Li showed increased Spr mRNA expression, protein levels, and histone acetylation in the Spr promoter. The increases in $S p r$ resulted in augmented levels of tetrahydrobioptherin (BH4), a cofactor involved in the biosynthesis of diverse neurotransmitters. Conversely, treatment with LTG and CBZ did not result in significant changes in Spr mRNA expression (Balasubramanian et al., 2015). A fourth study analyzed the potential of mood stabilizers VPA's, CBZ's, and LTG's affect on global DNA methylation, histone acetylation, and methylation of the GLT-1 promoter, which encodes for the excitatory amino acid transporter 2 (EAAT2), a research target for MDD and BD, in astroglial cultures of Sprague-Dawley rats (Perisic et al., 2010; Blacker et al., 2019). Only VPA induced histone hyperacetylation of $\mathrm{H} 3$ and $\mathrm{H} 4$, and DNA methylation, both reversible after drug removal. VPA also led to reduced GLT-1promoter methylation 
TABLE 2 | Summaries of studies in human cell lines included in the systematic analysis.

\begin{tabular}{|c|c|c|c|c|c|}
\hline $\begin{array}{l}\text { Reference } \\
\text { (by year) }\end{array}$ & Nature of research & Species, tissue & $\begin{array}{c}\text { Mood } \\
\text { stabilizer }\end{array}$ & $\begin{array}{l}\text { Targeted } \\
\text { gene }\end{array}$ & Data extracted \\
\hline $\begin{array}{l}\text { (Dyrvig } \\
\text { et al., 2019) }\end{array}$ & $\begin{array}{l}\text { Explore the epigenetic regulation of } \\
\text { CHRNA7 as a response predictor and } \\
\text { modulator to a7 nAChR agonists. }\end{array}$ & $\begin{array}{l}\text { Human, } \\
\text { adenocarcinoma } \\
\text { and } \\
\text { neuroblastoma } \\
\text { cells }\end{array}$ & VPA & CHRNA7 & $\begin{array}{l}\text { VPA caused transcriptional upregulation of CHRNA7, which } \\
\text { correlated with decreased DNA methylation. } \\
\text { Concomitant administration of VPA and nicotine in SH-SY5Y cells } \\
\text { increased CHRNA7 expression and decreased methylation levels. }\end{array}$ \\
\hline $\begin{array}{l}\text { (Manca } \\
\text { et al., 2019) }\end{array}$ & $\begin{array}{l}\text { Analyze } M A O A \text { regulation in a human } \\
\text { female heterozygous cell line to explore } \\
\text { the transcriptional and epigenetic } \\
\text { variation at the UVNTR domain in } \\
M A O A \text { in response to sodium VPA. }\end{array}$ & $\begin{array}{l}\text { Human, } \\
\text { neuroblastoma } \\
\text { cells }\end{array}$ & VPA & $\begin{array}{l}\text { UVNTR } \\
\text { MAOA }\end{array}$ & $\begin{array}{l}\text { Altered methylation pattern at the UVNTR domain when exposed to } \\
\text { sodium VPA. }\end{array}$ \\
\hline $\begin{array}{l}\text { (Billingsley } \\
\text { et al., 2018) }\end{array}$ & $\begin{array}{l}\text { Cells were exposed to cocaine or Li to } \\
\text { determine if transcriptional activity at } \\
\text { CACNA1C locus was regulated in a } \\
\text { stimulus-inducible manner. }\end{array}$ & $\begin{array}{l}\text { Human, } \\
\text { neuroblastoma } \\
\text { cells }\end{array}$ & $\mathrm{Li}$ & CACNA1C & $\begin{array}{l}\text { Exposure to Li increased expression from all three CACNA1C } \\
\text { promoter gene constructs, which encode for Cav1.2. }\end{array}$ \\
\hline $\begin{array}{l}\text { (Zong et al., } \\
\text { 2017) }\end{array}$ & $\begin{array}{l}\text { Assess response of GABRB2 mRNA } \\
\text { expression alterations to epigenetic } \\
\text { modifications with 5-azacytidine or } \\
\text { VPA. }\end{array}$ & $\begin{array}{l}\text { Human, } \\
\text { neuroblastoma } \\
\text { cells }\end{array}$ & VPA & GABRB2 & $\begin{array}{l}\text { VPA caused an upregulation of GABRB2 mRNA expression } \\
\text { accompanied by histone } 4 \text { hyperacetylation at the GABRB2 Yi6 } \\
\text { region. }\end{array}$ \\
\hline $\begin{array}{l}\text { (Dyrvig } \\
\text { et al., 2017) }\end{array}$ & $\begin{array}{l}\text { Explore the effect of three different } \\
\text { mood stabilizers on BRD1 expression } \\
\text { and changes in DNA methylation. }\end{array}$ & $\begin{array}{l}\text { Human, } \\
\text { neuroblastoma } \\
\text { cells }\end{array}$ & $\begin{array}{l}\text { VPA, Li, } \\
\text { and CBZ }\end{array}$ & BRD1 & $\begin{array}{l}\text { Li caused a } 13 \% \text { decreased expression of } B R D 1 \text { exon } 1 \mathrm{~B} \\
\text { containing transcripts. VPA caused a } 10 \% \text { increase of the } \\
\text { expression of } B R D 1 \text { exon } 1 \mathrm{~A} . \mathrm{CBZ} \text { caused a } 15 \% \text { increase in } \\
\text { expression of total BRD1. }\end{array}$ \\
\hline $\begin{array}{l}\text { (Asai et al., } \\
\text { 2013) }\end{array}$ & $\begin{array}{l}\text { Perform a comprehensive and site- } \\
\text { specific analysis (DNA methylation } \\
\text { status) of the epigenetic effects of three } \\
\text { mood stabilizers. }\end{array}$ & $\begin{array}{l}\text { Human, } \\
\text { neuroblastoma } \\
\text { cells }\end{array}$ & $\begin{array}{l}\text { VPA, Li, } \\
\text { and } \mathrm{CBZ}\end{array}$ & $\begin{array}{l}\text { BDNF and } \\
\text { SLC6A4 }\end{array}$ & $\begin{array}{l}\text { Comprehensive analysis indicated that all three mood stabilizers had } \\
\text { a propensity to increase DNA methylation. All three stabilizers were } \\
\text { associated with hypomethylation of SLC6A4 CpG3 and CpG4, while } \\
\text { level of DNA methylation of promoter IV of BDNF was not } \\
\text { significantly affected by any of the studied drugs. }\end{array}$ \\
\hline $\begin{array}{l}\text { (Kao et al., } \\
\text { 2013) }\end{array}$ & $\begin{array}{l}\text { To investigate the activation of FGF1 } \\
1 B \text { promoter by VPA through inhibition } \\
\text { of HDAC and GSK-3 activities. }\end{array}$ & $\begin{array}{l}\text { Human, } \\
\text { glioblastoma } \\
\text { cells }\end{array}$ & $\begin{array}{l}\text { VPA and } \\
\text { Li }\end{array}$ & $\begin{array}{l}\text { FGF1, } \\
R F X 2 \text {, and } \\
R F X 3\end{array}$ & $\begin{array}{l}\text { VPA-treated cells showed an increased expression of RFX2 and } \\
\text { RFX3, which significantly increased FGF1 } 1 \mathrm{~B} \text { expression. } \\
\text { VPA activated FGF1 } 1 \mathrm{~B} \text { promoter activity through inducing histone } \\
\text { acetylation around the RR2 regulatory region. } \\
\text { Li enhanced the expression of FGF1 } 1 \mathrm{~B} \text { and RFX2 though inhibition } \\
\text { of GSK-3 activity. }\end{array}$ \\
\hline
\end{tabular}

VPA, valproic acid; CBZ, carbamazepine; Li, lithium.

at three $\mathrm{CpG}$ sites, enriched acetylation of $\mathrm{H} 3$ and $\mathrm{H} 4$, and a dose dependent increase of GLT-1 mRNA. LTG and CBZ failed to produce significant changes (Perisic et al., 2010).

A preliminary study by Wang et al. (2012) examined rat astrocytes and the effect of VPA on the synaptic excitatory/ inhibitory balance through modulation of cell adhesion molecules (CAM) and extracellular matrices (ECM), which are known to be involved in the formation and maturation of synapses (Dalva et al., 2007). This paper evaluated VPAinduced changes on mRNA levels of neuroligin-1 (NLGN) and neuregulin-1 (NRG1), which are CAMs involved in the regulation of glutamatergic and GABAergic synapses (Craig and Kang, 2007), and neuronal pentraxin-1 (NPTX1) and thrombospondin-3 (TSP3), which are ECMs that promote synaptogenesis (Christopherson et al., 2005; Koch and Ullian, 2010). Exposure to VPA significantly increased the mRNA levels of the four molecules in a time- and concentration-dependent manner in astrocytes (Wang et al., 2012).

Activity on genes encoding for pro- and anti-apoptotic proteins have also been reported, highlighting them as a potential therapeutic target in $\mathrm{BD}$, a disorder were neuronal resilience and plasticity cascades are altered (Schloesser et al., 2008). A novel study in Sprague Dawley rats identified that LTG had protective effects against glutamate excitotoxicity through HDAC inhibition and $\mathrm{Bcl}-2$ upregulation in primary neuronal cerebellar granule cells (CGC) (Leng et al., 2013). LTG pretreatment provided a dose- and time-dependent protection against glutamate toxicity and decrease in HDAC activity, sparing histone acetyltransferase (HAT) activity (Leng et al., 2013). LTG treatment caused moderate time-dependent increase of histones $\mathrm{H} 3$ and $\mathrm{H} 4$ acetylation levels. Inhibition of HDAC activity by LTG was less robust, however, than VPA-related inhibition. In this study, the anti-apoptotic $\mathrm{Bcl}-2$ gene was positively impacted with LTG treatment. Concentrationdependent increases in Bcl-2 mRNA levels with an associated increase of Bcl-2 protein were observed after exposure of CGC cultures to incremental doses of LTG $(0-100 \mu \mathrm{M})$ for 2 days (Leng et al., 2013).

The relevance of $B c l-2$ has risen since recent links between $B c l-2$ dysregulation and mood disorders were identified (Schloesser et al., 2008), and the mechanisms through which Li and VPA impact cellular plasticity cascades. One study described the influence of lithium on the expression of neuroprotective genes BDNF, Bcl-2, and Bcl-XL and pro-apoptotic genes Bax, $B A D$ and caspase-3 in rat hippocampal neurons (Dwivedi and Zhang, 2015). After exposure to $\mathrm{Li}$, expression of $\mathrm{Bcl}-2$ and $\mathrm{Bcl}$ - 
TABLE 3 | Summaries of studies on human subjects affected by a major psychiatric disorder included in the systematic analysis.

\begin{tabular}{|c|c|c|c|c|c|}
\hline $\begin{array}{l}\text { Reference } \\
\text { (by year) }\end{array}$ & Nature of research & $\begin{array}{l}\text { Species, } \\
\text { tissue }\end{array}$ & $\begin{array}{l}\text { Mood } \\
\text { stabilizer }\end{array}$ & Targeted gene & Data extracted \\
\hline $\begin{array}{l}\text { (Bengesser } \\
\text { et al., 2018) }\end{array}$ & $\begin{array}{l}\text { Evaluate and compare methylation of } \\
\text { ARNTL between bipolar disorder and } \\
\text { controls. }\end{array}$ & $\begin{array}{l}\text { Human, } \\
\text { blood }\end{array}$ & $\mathrm{Li}$ & ARNTL & $\begin{array}{l}\text { Significant association between methylation } A R N T L \text { region } \\
\text { cg05733463 and Li intake. }\end{array}$ \\
\hline $\begin{array}{l}\text { (Houtepen } \\
\text { et al., 2016) }\end{array}$ & $\begin{array}{l}\text { To examine the DNA methylation } \\
\text { signatures of psychotropic drugs in BD } \\
\text { patients through genome-wide and } \\
\text { candidate-genes approaches. }\end{array}$ & $\begin{array}{l}\text { Human, } \\
\text { PBMC }\end{array}$ & $\begin{array}{l}\text { Li, LTG, } \\
\text { VPA, } \\
\text { CBZ }\end{array}$ & $\begin{array}{l}\text { RELN, SLC1A2, } \\
\text { MTNR1A, IGF2, } \\
\text { H19, BDNF, } \\
\text { SLC6A4, and } \\
\text { GAD1. }\end{array}$ & $\begin{array}{l}\text { Association between specific drugs and loci methylation } \\
\text { status did not provide any replication for the candidate } \\
\text { genes after false discovery rate correction, most likely as a } \\
\text { consequence of limited power. }\end{array}$ \\
\hline $\begin{array}{l}\text { (Burghardt } \\
\text { et al., 2016) }\end{array}$ & $\begin{array}{l}\text { Identify and validate a candidate gene } \\
\text { associated with atypical antipsychotics- } \\
\text { induced insulin resistance through a cross } \\
\text { sectional approach of subjects with BDI } \\
\text { treated with Li monotherapy or atypical } \\
\text { antipsychotics. }\end{array}$ & $\begin{array}{l}\text { Human, } \\
\text { peripheral } \\
\text { blood }\end{array}$ & $\mathrm{Li}$ & $\begin{array}{l}\text { FAR2, global DNA } \\
\text { methylation }\end{array}$ & $\begin{array}{l}\text { No association between FAR2 methylation levels and an } \\
\text { insulin-resistant state in subjects treated with Li, which may } \\
\text { be affected by the small sample size in this group. }\end{array}$ \\
\hline $\begin{array}{l}\text { (Burghardt } \\
\text { et al., 2015) }\end{array}$ & $\begin{array}{l}\text { To examine the relationship between } \\
\text { atypical antipsychotic or mood stabilizer } \\
\text { therapy and insulin resistance and degree } \\
\text { of peripheral blood DNA methylation in } \\
\text { subjects with BDI. }\end{array}$ & $\begin{array}{l}\text { Human, } \\
\text { leukocytes }\end{array}$ & $\begin{array}{l}\text { LTG, Li, } \\
\text { VPA }\end{array}$ & $\begin{array}{l}\text { Global DNA } \\
\text { methylation }\end{array}$ & $\begin{array}{l}\text { Regarding the mood stabilizer group, global methylation } \\
\text { values were not significantly reduced, which may be } \\
\text { affected by the small sample size in this group. }\end{array}$ \\
\hline $\begin{array}{l}\text { (Dell'Osso } \\
\text { et al., 2014) }\end{array}$ & $\begin{array}{l}\text { Cross-sectional analysis of differences in } \\
B D N F \text { promoter gene methylation in } \\
\text { patients with mood disorders. DNA } \\
\text { methylation was also analyzed on the basis } \\
\text { of the pharmacotherapy. }\end{array}$ & $\begin{array}{l}\text { Human, } \\
\text { PBMC }\end{array}$ & Li, VPA & $B D N F$ & $\begin{array}{l}\text { Both Li and VPA showed a not significant decrease in DNA } \\
\text { methylation level at BDNF gene promoter when compared } \\
\text { to antidepressants and atypical antipsychotics. } \\
\text { Lower methylation levels seen in BD I subjects could be } \\
\text { associated with the fact that they were mainly treated with } \\
\text { mood stabilizers. } \\
\text { Relation between mood stabilizer dose and methylation } \\
\text { level was not specified. }\end{array}$ \\
\hline $\begin{array}{l}\text { (Huzayyin } \\
\text { et al., 2014) }\end{array}$ & $\begin{array}{l}\text { Investigate the relationship between DNA } \\
\text { methylation in patients with BD and } \\
\text { excellent response to Li, their affected and } \\
\text { unaffected relatives and controls. }\end{array}$ & $\begin{array}{l}\text { Human, } \\
\text { lymphoblast }\end{array}$ & $\mathrm{Li}$ & $\begin{array}{l}\text { Global DNA } \\
\text { methylation, GPx }\end{array}$ & $\begin{array}{l}\text { Global methylation was decreased in BD subjects and their } \\
\text { relatives compared to control subjects. }\end{array}$ \\
\hline $\begin{array}{l}\text { (D'Addario } \\
\text { et al., 2012) }\end{array}$ & $\begin{array}{l}\text { Investigate role of DNA methylation in the } \\
\text { regulation of } B D N F \text { transcription and } \\
\text { assess differences across pharmacological } \\
\text { treatment and other groups. }\end{array}$ & $\begin{array}{l}\text { Human, } \\
\text { PBMC }\end{array}$ & Li, VPA & $B D N F$ & $\begin{array}{l}\text { DNA methylation was significantly reduced in subjects } \\
\text { under therapy with Li or VPA compared with treatment with } \\
\text { other drugs. BDNF mRNA levels were not measured. }\end{array}$ \\
\hline $\begin{array}{l}\text { (Gavin } \\
\text { et al., 2009) }\end{array}$ & $\begin{array}{l}\text { Investigate an in vitro and an in vivo } \\
\text { approach for measuring chromatin } \\
\text { remodeling in real clinical time. In vitro } \\
\text { approach was performed through cultured } \\
\text { human lymphocytes with VPA and the in } \\
\text { vivo approach studied SCZ and BD } \\
\text { subjects treated with VPA for } 4 \text { weeks. }\end{array}$ & $\begin{array}{l}\text { Human, } \\
\text { lymphocytes }\end{array}$ & VPA & $\begin{array}{l}\text { GAD67, H3K9, } \\
\text { K14ac }\end{array}$ & $\begin{array}{l}\text { In vitro exposure to VPA significantly increased H3K9,K14ac } \\
\text { protein levels and GAD67 expression. } \\
\text { VPA treatment for } 4 \text { weeks significantly increased H3K9, } \\
\text { K14ac protein levels across all subjects, being more } \\
\text { notorious in BD subjects. VPA showed a dose response } \\
\text { effect on the mRNA expression of GAD67 and H3K9,14ac } \\
\text { protein levels. }\end{array}$ \\
\hline
\end{tabular}

VPA, valproic acid; LTG, lamotrigine; CBZ, carbamazepine; Li, lithium.

TABLE 4 | Summaries of studies on more than one type of populations included in the systematic analysis.

\begin{tabular}{|c|c|c|c|c|c|}
\hline $\begin{array}{l}\text { Reference } \\
\text { (by year) }\end{array}$ & Nature of research & Species, tissue & $\begin{array}{l}\text { Mood } \\
\text { stabilizer }\end{array}$ & $\begin{array}{l}\text { Targeted } \\
\text { gene }\end{array}$ & Data extracted \\
\hline $\begin{array}{l}\text { (Kaminsky } \\
\text { et al., 2015) }\end{array}$ & $\begin{array}{l}\text { Explore the association of mood stabilizers with } \\
\text { epigenetic changes in KCNQ3 gene. }\end{array}$ & $\begin{array}{l}\text { Human, postmortem PFC } \\
\text { tissue } \\
\text { Human, neuroblastoma } \\
\text { cells } \\
\text { Rat, PFC tissue }\end{array}$ & VPA, Li & KCNQ3 & $\begin{array}{l}\text { In human sample, Li or VPA increased DNA } \\
\text { methylation. } \\
\text { Treatment of neuroblastoma cells did not } \\
\text { produced significant methylation changes with } \\
\text { either stabilizer. } \\
\text { In rats, Li was associated with a small significant } \\
\text { elevation of mean KCNQ3 exon } 11 \text { DNA } \\
\text { methylation. }\end{array}$ \\
\hline $\begin{array}{l}\text { (Kakiuchi } \\
\text { et al., 2003) }\end{array}$ & $\begin{array}{l}\text { To determine the contribution of } X B P 1 \text { gene and } \\
\text { ATF6, the gene upstream of } X B P 1 \text {, as risk } \\
\text { factors for } B D \text { and the effect of mood stabilizers } \\
\text { on gene expression. }\end{array}$ & $\begin{array}{l}\text { Human, lymphoblasts and } \\
\text { neuroblastoma cells }\end{array}$ & $\begin{array}{l}\text { VPA, Li, } \\
\text { and CBZ }\end{array}$ & $\begin{array}{l}\text { ATF6 and } \\
\text { HSPA5 }\end{array}$ & $\begin{array}{l}\text { Of the three mood stabilizers, only VPA had a } \\
\text { significant effect on ATF6 mRNA expression but } \\
\text { not HSPA5 mRNA levels. }\end{array}$ \\
\hline
\end{tabular}

VPA, valproic acid; CBZ, carbamazepine; Li, lithium. 
$X L$ genes were increased in a dose-dependent manner, while expression of Bax, $B A D$, and caspase- 3 was decreased by both doses of $\mathrm{Li}(1 \mathrm{mM}$ and $2 \mathrm{mM}$ ), with magnitude of change being higher at $2 \mathrm{mM}$ (Dwivedi and Zhang, 2015). The mRNA expression of BDNF was increased by $67 \%$ when exposed to $\mathrm{Li}$ at $1 \mathrm{mM}$ and was fully sustained at $2 \mathrm{mM}$, especially on specific $B D N F$ promoter exon IV, where methylation was decreased by $\mathrm{Li}$; protein levels of $B D N F$ were increased by $53 \%$ and $89 \%$ for 1 $\mathrm{mM}$ and $2 \mathrm{mM} \mathrm{Li}$, respectively (Dwivedi and Zhang, 2015). One additional study focused on changes in BDNF, Arc, and epigenetic regulators HDAC-1, -2 , and -5 in Sprague-Dawley rats' hippocampi after exposure to VPA, lurasidone, or a combination of both (Calabrese et al., 2013). Regarding treatment with VPA only, an increase in BDNF mRNA levels in ventral and dorsal hippocampus was reported, as well as proBDNF and mature BDNF levels. Arc mRNA levels were also upregulated after exposure to VPA. Arc and BDNF expression increased more consistently with combination therapy, and HDAC isoform mRNA levels were significantly decreased (Calabrese et al., 2013).

Four papers examined the epigenetic changes secondary to VPA administration on RELN (reelin) and $G A D_{67}$ in METinduced mouse models of SCZ (Tremolizzo et al., 2002; Dong et al., 2005; Tremolizzo et al., 2005; Dong et al., 2010). RELN expression, synthetized by GABAergic interneurons, is reduced in neocortex of SCZ and $\mathrm{BD}$, paralleled by a down-regulation of $G A D_{67}$ levels, responsible for regulating cortical GABA levels (Guidotti et al., 2000; Guidotti et al., 2016). When comparing randomly sampled MET-injected populations of heterozygous reeler mice (reelin-deficient) versus wild type mice, VPA increased $\mathrm{H} 3$ histone acetylation, and reversed decreased mRNA expression of RELN and $G A D_{67}$ induced by Lmethionine in prefrontal cortices of both populations. VPA failed to modify $\mathrm{H} 4$ acetylation and $G A D_{65}$ expression (Tremolizzo et al., 2002). Likewise, in Swiss albino mice's frontal cortices, VPA prevented MET-induced RELN promoter hypermethylation and reduced the $M e C P 2$ binding to RELN and $G A D_{67}$ in frontal cortices (Dong et al., 2005). Upregulated $\mathrm{MeCP} 2$ binding is associated with hypermethylation of $\mathrm{CpG}$ island promoters and increased recruitment of HDACs which favors gene transcriptional repression (Dong et al., 2005). VPA action on histone acetylation and methylation dynamics in RELN promoter was confirmed in MET-treated B6C3Fe male mice in which enhanced acetylation of $\mathrm{H} 3$ histone and prevention of MET-induced RELN hypermethylation and mRNA downregulation was observed after exposure to VPA (Tremolizzo et al., 2005). In this study, correction of Lmethionine-related behavioral deficits was also observed after VPA treatment. More recently, the association between inhibition of RELN expression and DNA methyltransferases (DNMT) was explored in Swiss albino mice to better determine the pathway through which VPA induces demethylation of RELN and $\mathrm{GAD}_{67}$ (Dong et al., 2010). Although this study confirmed previous evidence of the association between overexpression of DNMT1 and DNMT3a in SCZ cortex and hypermethylation of the promoters of RELN and $G A D_{67}$ (Veldic et al., 2004), promoter demethylation induced by VPA was not caused by a decrease of DNMT activity or levels, but by increased acetylation of histones by HDAC inhibition (Dong et al., 2010). A fifth study examined the impact of VPA on growth arrest and DNA-damage-inducible beta (Gadd45- $\beta$ ) expression and binding properties (Matrisciano et al., 2011). In mice hippocampi, frontal cortices, and cerebellums, VPA was reported to robustly upregulate Gadd45$\beta$ expression by activation of DNA demethylation, a 2- to 3-fold increase of Gadd45- $\beta$ mRNA levels, and an increased binding to reelin, $G A D_{67}$, and $B D N F-I X$ promoters (Matrisciano et al., 2011).

VPA- and Li-mediated epigenetic effects on Lepr, leptin receptor gene, implicated in regulation of mood and satiety, were explored in rats' hippocampi (Lee et al., 2015). Both agents produced an augment in the expression of Lepr, although VPA showed a more significant increase (127.4\% vs. 32.6\%). Histone $\mathrm{H} 3$ methylation and acetylation were induced by VPA and Li; for $\mathrm{Li}$, a more pronounced demethylation of $\mathrm{H} 3$ was observed. Another gene involved in metabolism, fibroblast growth factor 21 (FGF21), and its effect after exposure to VPA, CBZ, LTG, and Li was studied by Leng et al. (2016) in rat primary cortical glial cells and C6 glioma cells. C6 and glial cells treated with either VPA or Li experienced a dose-dependent increase in FGF21 mRNA levels, while LTG and CBZ were ineffective. VPA, LTG and, less potently, CBZ significantly increased H3 acetylation levels (Leng et al., 2016). In another study, further examination of the mechanisms underlying melatonin $M T_{1}$ receptors' upregulation by VPA was performed in rat glioma cells (Bahna and Niles, 2017). Exposure to VPA increased expression of $M T_{1}$ mRNA and acetylation of $\mathrm{H} 3 \mathrm{~K} 9$ across the receptor's promoter.

\section{In Vitro Human Cell Line Model}

Study of human neuroblastoma and glioblastoma cells offer a window of what might happen in vivo and might be better models than HeLa adenocarcinoma cells to investigate the effects of mood stabilizers, due to their neuronal characteristics (Dyrvig et al., 2017).

CHRNA7, encoding the $\alpha 7$ nicotinic acetylcholine receptor (nAChR) has been linked to SCZ (Stephens et al., 2009). In one study, VPA was found to cause an upregulation of CHRNA7 expression, correlating with decreased DNA methylation on HeLa cells, suggesting a potential reversing effect of pharmacotherapy on an epigenetic mechanism (Dyrvig et al., 2019). A dose-dependent effect was observed; while treatment with $0.3 \mathrm{mM}$ VPA produced a 4 -fold upregulation of the expression, $0.6 \mathrm{mM}$ VPA resulted in an 8.5-fold increase. Concomitant exposure to VPA and nicotine did not produce additional effects of CHRNA7 in HeLa cells but increased CHRNA7 expression, and decreased DNA methylation, in SHSY5Y cells.

Necessary for acetylation of H3K14, dysregulations of bromodomain-containing protein 1 (BRD1), and its encoding gene $B R D 1$ have been linked to SCZ and $\mathrm{BD}$ and show stress- 
related changes in expression (Christensen et al., 2012; Dyrvig et al., 2017). The effects of CBZ, VPA, and Li on the BRD1 gene was studied in cultured neuroblastoma cells (SH-SY5Y) providing evidence that these mood stabilizers altered the expression of BRD1 by mechanisms other than DNA methylation, which remained unchanged after exposure to these agents (Christensen et al., 2012; Dyrvig et al., 2017). Increased expression of total BRD1 with CBZ was observed, while VPA increased the expression of exon 1C, and Li treatment decreased the expression of exon 1B.

Two papers examined epigenetic changes induced by mood stabilizers on genes involved in synaptic processes, GABRB2 (encoding a GABA receptor subunit), and CACNA1C (encoding a calcium channel) (Zong et al., 2017; Billingsley et al., 2018). $\mathrm{GABA}_{\mathrm{A}}$ receptor $\beta_{2}$-subunit gene (GABRB2) has been linked to SCZ and BD in multiple studies (Chen et al., 2009; Zhao et al., 2012). Zong et al. (Zong et al., 2017) assessed the response of deregulated GABRB2 mRNA expression to epigenetic modifications with VPA. Treatment of neuroblastoma cells (IMR-32) with VPA not only induced hyperacetylation of histone $\mathrm{H} 4$ and promoter regions, but also had a five-fold increase in mRNA expression providing further evidence of GABAergic dysfunction in psychotic disorders. Billingsley et al. (2018) focused on the effect of lithium and cocaine exposure in the transcriptional activity on CACNA1C gene, encoding for the L-type alc sub-unit of the voltage-dependent calcium channel, Cav1.2, the most abundant human neuronal L-type calcium channel and a significant risk gene for BD and SCZ (Moon et al., 2018; Zhu et al., 2019). Treatment of neuroblastoma cells (SH-SY5Y) with Li resulted in an increased expression of all three studied CACNA1C promoters (Billingsley et al., 2018). A gene-specific analysis of DNA methylation status of $B D N F$ and SLC6A4 genes after exposure to VPA, Li, and CBZ showed that all three mood stabilizers decreased, at different concentrations, methylation of CpG sites of SLC6A4 but not BDNF promoter IV in neuroblastoma cells (Asai et al., 2013). This study was limited by the lack of testing of treatment duration but provided, nonetheless, insights into epigenetic regulation exerted by mood stabilizers in two genes involved in synaptic regulation and associated with mood disorders.

Epigenetic variations secondary to VPA in the monoamine system were explored by Manca et al. (Manca et al., 2019) through analysis of MAOA gene regulation. Neuroblastoma cells (SH-SY5Y), which is a female cell line, showed a decreased methylation pattern at the uVNTR domain of $M A O A$ after exposure to VPA. This study is particularly relevant due to the heterozygous nature of the MAOA gene, located on the $\mathrm{X}$ chromosome, in females and because findings showed a different pattern of binding of transcription factors on each X chromosome allele.

Two studies provided insights on the influence of mood stabilizers on neuroprotective- and transcription-related genes (Asai et al., 2013; Kao et al., 2013). Activation of FGF-1B gene promoter, member of the fibroblast growth factor family, by VPA- and Li-related inhibition of HDACs and GSK-3 pathway in glioblastoma cells was investigated (Kao et al., 2013). VPA- treated cells showed increased expression levels of transcriptional factors $R F X 2$ and $R F X 3$, which bind to $F G F-1 B$ promoter, as well as activation of FGF-1B promoter through acetylation of histone H3 secondary to HDAC inhibition. Through a different pathway, $\mathrm{Li}$, a well-known GSK-3 inhibitor, enhanced the expression levels of FGF-1B and RFX2 (Kao et al., 2013). This study suggests that FGF1 is an important target of mood stabilizers through different pathways. Asai et al. performed an analysis of the DNA methylation status of $B D N F$ and SLC6A4 after exposure to VPA, CBZ, and Li. Findings suggested a propensity of all three mood stabilizers to alter global DNA methylation and were associated with decreased methylation of SLC6A4 CpG3 and CpG4. DNA methylation status of BDN promoter IV was not significantly altered by any of the studied stabilizers (Asai et al., 2013).

\section{Human Studies}

Studies comparing the effects of $\mathrm{Li}$ and VPA, alone or in combination with other medications, on DNA methylation of $B D N F$ gene of subjects with $\mathrm{BD}$ or MDD were similar. A more significant reduction in DNA methylation level was observed with VPA and Li when compared to other medications (D'Addario et al., 2012). Lower methylation levels during manic states observed in this study could be attributed to the use of higher doses of mood stabilizers than during depressive or euthymic states. More recently, this same group generated data suggesting a decrease in DNA methylation level at $B D N F$ gene promoter in patients under treatment with VPA or Li, although due to lack of reporting on used doses, a dosedependent effect on methylation levels remains uncertain (Dell'Osso et al., 2014).

Lithium was also associated with reduced methylation at one site in the $5^{\prime}$ regulatory region of ARNTL (cg05733463) when compared to individuals with $\mathrm{BD}$ not taking lithium, suggesting an activation of epigenetic marks with an associated increased gene expression (Bengesser et al., 2018). ARNTL, a core component of the circadian clock, is involved in the expression of the MAOA gene, therefore imbalances in the relation between circadian rhythms and neurotransmitter degradation may contribute towards an increased BD susceptibility (Geoffroy, 2018). Effects of Li on FAR2 (fatty acyl CoA reductase 2) methylation and insulin resistance was done in another paper, although the main focus of the research was on second generation antipsychotics (Burghardt et al., 2016). Only 25\% of the 72 subjects included were on Li monotherapy, so lack of association between FAR2 methylation levels and Li treatment could be a consequence of the small sample size. A previous study by Burghardt et al. (Burghardt et al., 2015) also compared global DNA methylation induced second generation antipsychotics versus Li, VPA, and LTG and insulin resistance. No change in global methylation was observed with mood stabilizers but, as in their subsequent study, the small size of the sample under mood stabilizer treatment (31 of 115 BD1 patients) was a significant limitation. Another study measured global DNA methylation and glutathione peroxidase (GPx) activity in subjects with $\mathrm{BD}$ and excellent response to $\mathrm{Li}$ 
monotherapy, in unaffected and affected relatives, and in healthy controls (Huzayyin et al., 2014). Interestingly, GPx activity was increased in affected relatives after treatment with $\mathrm{Li}$ and a significant, negative correlation between GPx activity and DNA methylation was observed. GPx levels have been reported to be reduced in postmortem prefrontal cortices in SCZ, MDD, and BD (Gawryluk et al., 2011).

Studies indicate that $G A D_{67}$ mRNA levels are reduced in postmortem brains of subjects diagnosed with SCZ and BD (Akbarian and Huang, 2006). Similar to findings in previously described animal studies, a dual in vivo and in vitro approach in humans consisting of 4-week treatment with VPA was found to upregulate, in response to dosage, the expression of $G A D_{67}$ in individuals with SCZ and BD, as well as H3K9 and H3K14 acetylation levels (Gavin et al., 2009). Cultured lymphocytes exposed to $0.7 \mathrm{mM}$ VPA showed a $383 \%$ increase in $G A D_{67}$ mRNA and an $89 \%$ increase in $\mathrm{H} 3 \mathrm{~K} 9 \mathrm{ac}$ and $\mathrm{H} 3 \mathrm{~K} 14$ while lymphocytes from SCZ and BD patients before and after treatment with VPA showed a significant increase in $G A D_{67}$ mRNA expression (Gavin et al., 2009). H3K9Ac is an epigenetic mark that typically indicates transcriptionally active chromatin (Qiao et al., 2015), therefore the $482 \%$ increase in $\mathrm{H} 3 \mathrm{~K} 9 \mathrm{ac} /$ $\mathrm{H} 3 \mathrm{~K} 14 \mathrm{ac}$ attachment to the $G A D_{67}$ promoter could predict a further increase in $G A D_{67}$ expression (Gavin et al., 2009).

DNA methylation signatures of psychotropic drugs on candidate-genes in 172 Dutch patients with BD were studied (Houtepen et al., 2016). Impact of the classic mood stabilizers VPA, CBZ, LTG, and Li were measured on RELN, SLCQA2, MTNR1A, IGF2, H19, BDNF, SLC6A4, and GAD1. No specific methylated $\mathrm{CpG}$ sites survived multiple testing correction; Q-Q (quantile-quantile) plot analysis and trend level results suggested that it was likely the result of limited statistical power, although VPA was significantly associated with altered methylation signatures (Houtepen et al., 2016).

It is worth mentioning that all studies on human subjects were performed on peripheral blood mononuclear cells (PBMC), widely used for DNA methylation studies and a model of epigenetic gene regulation in the brain (Gavin and Sharma, 2010; Dell'Osso et al., 2014). Despite DNA methylation being subject to tissue-specific variations in brain and blood, PBMC is considered a reliable biomarker of brain activity (Davies et al., 2012).

\section{Studies With Animal Models, Human Cell Lines, and Psychiatric Populations}

Two studies performed gene-specific analysis with samplespecific approaches on rodents, human cell lines, and/or patients with BD (Kakiuchi et al., 2003; Kaminsky et al., 2015). Kakiuchi et al. studied the effect of mood stabilizers (Li, VPA, and $\mathrm{CBZ}$ ) on activating transcription factor gene (ATF6), and heat shock protein family A member 5 gene (HSPA5), on lymphoblastoid cells in two pairs of monozygotic twins affected with BD, a pair of healthy twins, and in neuroblastoma (SHSY5Y) cells (Kakiuchi et al., 2003). Only VPA significantly increased mRNA expression of ATF6 and induced HSPA5 gene expression through upregulation of XBP1 gene. The second study explored the association of mood stabilizers, VPA and $\mathrm{Li}$, with epigenetic changes in KCNQ3 gene, which encodes for potassium voltage-gated channel, subfamily Q member 3 (Kaminsky et al., 2015). DNA methylation and gene expression levels were tested in four different samples 1) a group comparing post-mortem prefrontal cortex tissue from $12 \mathrm{BD}$ subjects versus 2) 10 control subjects, 3) a sample of human neuroblastoma cell line, and 4) prefrontal cortices of Brown-Norway rats. On the first and fourth groups, increased DNA methylation was observed after treatment with VPA and Li, while no changes were observed in neuroblastoma cells (Kaminsky et al., 2015).

\section{Risk of Bias}

Every article was appraised for quality using a modified published process (du Prel et al., 2009); all papers met a quality score of moderate or high.

\section{DISCUSSION}

\section{Summary of Main Findings}

This systematic review explored the epigenetic changes induced by VPA, Li, CBZ, and LTG in major psychiatric disorders. Despite the genetic complexity of mental illnesses, evidence suggest that epigenome can be targeted by mood stabilizers in psychiatric disorders which can potentially translate into longterm illness trajectory changes (Ludwig and Dwivedi, 2016), although, aside from VPA and Li, the evidence found was limited. Currently, only VPA and Li have shown to consistently induce epigenetic changes while LTG and CBZ have shown less consistent evidence, in part due to the lack of studies or to small sample sizes. Mood stabilizers exert their actions not only through histone deacetylase inhibition, but also through downregulation of methylation of cytosines in $\mathrm{CpG}$ dinucleotides, increased histone activity, and induction of RNA, which leads to an augmentation of gene expression (MachadoVieira et al., 2011; Houston et al., 2013). Previously identified disease-associated alterations in epigenetic markings of specific genes were susceptible to mood stabilizers, according to our findings.

We found few studies primarily focusing on the epigenetic effects of CBZ and LTG. This is relevant because both agents have Level 1 evidence for treatment of different phases of BD and are used in multiple psychiatric disorders (Reid et al., 2013; Yatham et al., 2018). While CBZ has been linked to moderate effects on global and gene-specific DNA methylation and HDAC inhibition, no clear conclusions can be drawn with respect to its epigenetic effects from available literature. Neuroprotective effects of LTG are believed to occur via inhibition of glutamate excitotoxicity, HDAC inhibition, histone acetylation, and activity on neuronal survival, and plasticity cascades. Up-regulation of anti-apoptotic gene $\mathrm{Bcl}-2$ has been studied as a potential mechanisms through which LTG exerts its epigenetic effects (Leng et al., 2013; Reid et al., 2013). It has been previously noted that perturbations in the apoptotic pathway could be 
involved in the pathogenesis of mood disorders (Zhang et al., 2014; Scaini et al., 2017) and that apoptotic regulator genes are targeted by VPA, Li, and LTG (Leng et al., 2013; Dwivedi and Zhang, 2015). Hence, the therapeutic potential of a synergistic neuroprotection from combined mood stabilizer therapy is a target for future investigation.

VPA is the prototypical HDAC inhibitor in major psychiatric disorders research. VPA relieves class I and II HDAC-dependent repression of transcription factors and increases histones $\mathrm{H} 3$ and $\mathrm{H} 4$ acetylation thereby enhancing activation of gene expression (Gottlicher et al., 2001). However, evidence suggests that VPA also exerts an effect on DNA methylation signatures, suggesting that VPA's activity over chromatin remodeling is not limited to HDACs inhibition (Houtepen et al., 2016; Pisanu et al., 2018). It is worth mentioning that HDAC inhibition and associated hyperacetylation by mood stabilizers is not absolute and that increased gene expression is a process that entails high levels of acetylation turnover and recruitment of HATs and HDACs to the active gene, suggesting that HDACs have both inhibitory and activating effects on transcription (Shahbazian and Grunstein, 2007). The latter may explain reports of increased HDAC expression after exposure to mood stabilizers described in several of the included studies (Ookubo et al., 2013; Liu et al., 2014; Bator et al., 2015). Likewise, since DNA methylation and histone modification pathways are not completely independent from each other (Cedar and Bergman, 2009), one mechanism by VPA can partially affect activity in the other. VPA-induced augmentation of methylcytosine-binding protein $\mathrm{MeCP} 2$ reported in animal models (Tremolizzo et al., 2002; Kim et al., 2008) suggests a relationship between DNA methylation and histone modification through HDACs recruitment to the methylated region by MeCP2 (Cedar and Bergman, 2009). VPA has also been reported to reduce methylation of gene promoters, thereby upregulating mRNA/expression of genes linked to SCZ and BD, indicating other mechanisms of action additional to HDAC inhibition (Dong et al., 2010). Animal and human studies generally reported that prominent epigenetic activity induced by valproic acid were exerted through different types of epigenetic mechanisms which led to a significant rise in the expression of silenced genes and regulation of altered transcriptional processes (Pisanu et al., 2018).

Although the precise mechanisms through which Li induces neuroprotective and neurotrophic activity are not yet fully elucidated, evidence suggests that activity on synapsis strength, cellular resilience, and glial function at a molecular level has a key role (Machado-Vieira, 2018). Overlapping activity on different pathways is characteristic of Li; however, epigenetic contributions on neurotrophins, apoptosis pathways, and glycogen synthase kinase-3 (GSK-3 $\beta$ ) stand out, among the included papers, as central targets of lithium (D'Addario et al., 2012; Kao et al., 2013; Dell'Osso et al., 2014; Dwivedi and Zhang, 2015). Several studies have identified a negative correlation between $\mathrm{Bcl}$-2 levels and positive symptoms in SCZ and manic symptoms in BD (Tsai et al., 2013; Chen et al., 2015), implying a dysregulation of apoptotic pathways in these disorders. Findings from our search reflect that Li can reverse not only the decreased levels of $B c l-2$ and $B c l-X L$ but also inhibit the expression of proapoptotic molecules such as $B A D, B A X$ and caspase-3 (Dwivedi and Zhang, 2015), highlighting the anti-apoptotic properties of this mood stabilizer. Similarly, expression of neuroprotective and anti-apoptotic protein $B D N F$ has been shown to be downregulated in BD, MDD, and SCZ (Machado-Vieira, 2018) but also epigenetically susceptible to mood stabilizers, including Li which exerts this activity mainly through DNA demethylation (D’Addario et al., 2012; Asai et al., 2013; Dwivedi and Zhang, 2015; Houtepen et al., 2016). Inhibition of GSK-3 $\beta$ activity on the intracellular signaling cascade has been one of the most welldefined mechanisms of action of Li (Beurel et al., 2015). One study reported an upregulation of the expression of plasticity proteins secondary to Li inhibition of GSK-3 activity (Kao et al., 2013). This is an especially important target for future research. Additionally, our systematic process corroborated the already defined role of $\mathrm{Li}$ as an HDAC inhibitor (Hobara et al., 2010; Ookubo et al., 2013).

\section{Strengths and Limitations}

While the epigenetic effects of mood stabilizers were evident, there are limitations to our results. First, most studies were limited by relatively small group samples and focused on cohortbased effects. This small group-based approach could hinder the identification of disease-relevant signals and be underpowered (Houston et al., 2013). Although subject to availability of samples and resources, future research should aim to increase the size of the studied groups. Second, studies were heterogeneous in methodology and studied population. Third, the majority of papers were focused on VPA, highlighting an urgent need to study the activity at an epigenetic level of other mood stabilizers. As we previously mentioned, although partly comparable, epigenetic patterns in peripheral blood cells are not an exact reflection of those in brain tissue (Davies et al., 2012; Pisanu et al., 2018), neuroblastoma cells, or animal models; however they are widely accepted as models for research of neuropsychiatric disorders in the absence of cell type-specific epigenome mappings (Houston et al., 2013). Finally, despite the measures taken to reduce publication bias through well-defined inclusion criteria, selective reporting cannot be excluded.

Several strengths were identified in our study. We reviewed a large body of evidence using criteria to capture a specific feature of mood stabilizers in SCZ, BD, and MDD and the quality of scientific publications were evaluated. Since we focused mainly on gene-specific effects of mood stabilizers, we identified small regulatory networks of epigenetic modulators of gene expression and neuroplasticity; consistency across studies was also found. To our knowledge, this systematic review is the first to attempt to summarize epigenetic changes secondary to non-antipsychotic mood stabilizers in three major psychiatric disorders.

\section{CONCLUSIONS}

In conclusion, available data confirms the effects of VPA and Li on the epigenome of genes associated with major psychiatric 
disorders and suggest that LTG and CBZ might have a greater role in the manipulation of epigenetic mechanisms, although further studies are required to elucidate their mechanisms of action. Our systematic review not only reflects the genetic complexity of major psychiatric disorders but, by summarizing the existing evidence, also underscores the ability of these classic mood stabilizers to target genes involved in synaptic plasticity, neuroplasticity, and transcription factors. A better understanding of the specific epigenetic changes induced by classic mood stabilizers in patients with major psychiatric disorders can lead towards more personalized interventions and to the development of new agents able to induce selective chromatin remodeling and gene-specific expression effects.

\section{REFERENCES}

Abdolmaleky, H. M., Gower, A. C., Wong, C. K., Cox, J. W., Zhang, X., Thiagalingam, A., et al. (2019). Aberrant transcriptomes and DNA methylomes define pathways that drive pathogenesis and loss of brain laterality/asymmetry in schizophrenia and bipolar disorder. Am. J. Med. Genet. B. Neuropsychiatr. Genet. 180 (2), 138-149. doi: 10.1002/ajmg.b.32691

Akbarian, S., and Huang, H. S. (2006). Molecular and cellular mechanisms of altered GAD1/GAD67 expression in schizophrenia and related disorders. Brain Res. Rev. 52 (2), 293-304. doi: 10.1016/j.brainresrev.2006.04.001

Alladi, C. G., Etain, B., Bellivier, F., and Marie-Claire, C. (2018). DNA Methylation as a Biomarker of Treatment Response Variability in Serious Mental Illnesses: A Systematic Review Focused on Bipolar Disorder, Schizophrenia, and Major Depressive Disorder. Int. J. Mol. Sci. 19 (10), 1-19. doi: 10.3390/ijms19103026

Allis, C. D., and Jenuwein, T. (2016). The molecular hallmarks of epigenetic control. Nat. Rev. Genet. 17 (8), 487-500. doi: 10.1038/nrg.2016.59

Asai, T., Bundo, M., Sugawara, H., Sunaga, F., Ueda, J., Tanaka, G., et al. (2013). Effect of mood stabilizers on DNA methylation in human neuroblastoma cells. Int. J. Neuropsychopharmacol. 16 (10), 2285-2294. doi: 10.1017/ S1461145713000710

Bahna, S. G., and Niles, L. P. (2017). Epigenetic induction of melatonin MT1 receptors by valproate: Neurotherapeutic implications. Eur. Neuropsychopharmacol. 27 (8), 828-832. doi: 10.1016/j.euroneuro.2017.06.002

Balasubramanian, D., Deng, A. X., Doudney, K., Hampton, M. B., and Kennedy, M. A. (2015). Valproic acid exposure leads to upregulation and increased promoter histone acetylation of sepiapterin reductase in a serotonergic cell line. Neuropharmacology 99, 79-88. doi: 10.1016/j.neuropharm.2015.06.018

Bator, E., Latusz, J., Radaszkiewicz, A., Wedzony, K., and Mackowiak, M. (2015). Valproic acid (VPA) reduces sensorimotor gating deficits and HDAC2 overexpression in the MAM animal model of schizophrenia. Pharmacol. Rep. 67 (6), 1124-1129. doi: 10.1016/j.pharep.2015.04.004

Bauer, M. S., and Mitchner, L. (2004). What is a "mood stabilizer"? An evidencebased response. Am. J. Psychiatry 161 (1), 3-18. doi: 10.1176/appi.ajp.161.1.3

Bengesser, S. A., Reininghaus, E. Z., Lackner, N., Birner, A., Fellendorf, F. T., Platzer, M., et al. (2018). Is the molecular clock ticking differently in bipolar disorder? Methylation analysis of the clock gene ARNTL. World J. Biol. Psychiatry 19 (sup2), S21-S29. doi: 10.1080/15622975.2016.1231421

Bernstein, B. E., Stamatoyannopoulos, J. A., Costello, J. F., Ren, B., Milosavljevic, A., Meissner, A., et al. (2010). The NIH Roadmap Epigenomics Mapping Consortium. Nat. Biotechnol. 28 (10), 1045-1048. doi: 10.1038/nbt1010-1045

Beurel, E., Grieco, S. F., and Jope, R. S. (2015). Glycogen synthase kinase-3 (GSK3): regulation, actions, and diseases. Pharmacol. Ther. 148, 114-131. doi: 10.1016/ j.pharmthera.2014.11.016

Billingsley, K. J., Manca, M., Gianfrancesco, O., Collier, D. A., Sharp, H., Bubb, V. J., et al. (2018). Regulatory characterisation of the schizophrenia-associated CACNA1C proximal promoter and the potential role for the transcription factor EZH2 in schizophrenia aetiology. Schizophr. Res. 199, 168-175. doi: $10.1016 /$ j.schres.2018.02.036

\section{DATA AVAILABILITY STATEMENT}

The original contributions presented in the study are included in the article/supplementary material, further inquiries can be directed to the corresponding author.

\section{AUTHOR CONTRIBUTIONS}

MG-R and MV conceived the research idea. MG-R, MV, and CB designed the search strategy. MG-R and MK performed the data collection. AH co-wrote and reviewed the paper. $\mathrm{PC}, \mathrm{MF}$, and $\mathrm{CB}$ reviewed and edited the paper. MV supervised the research.

Blacker, C. J., Millischer, V., Webb, L. M., Ho, A. M. C., Schalling, M., Frye, M. A. et al. (2019). EAAT2 as a Research Target in Bipolar Disorder and Unipolar Depression: A Systematic Review. Mol. Neuropsychiatry 1-16. doi: 10.1159/ 000501885

Burghardt, K. J., Goodrich, J. M., Dolinoy, D. C., and Ellingrod, V. L. (2015). DNA methylation, insulin resistance and second-generation antipsychotics in bipolar disorder. Epigenomics 7 (3), 343-352. doi: 10.2217/epi.15.5

Burghardt, K. J., Goodrich, J. M., Dolinoy, D. C., and Ellingrod, V. L. (2016). Genespecific DNA methylation may mediate atypical antipsychotic-induced insulin resistance. Bipolar Disord. 18 (5), 423-432. doi: 10.1111/bdi.12422

Calabrese, F., Luoni, A., Guidotti, G., Racagni, G., Fumagalli, F., and Riva, M. A. (2013). Modulation of neuronal plasticity following chronic concomitant administration of the novel antipsychotic lurasidone with the mood stabilizer valproic acid. Psychopharmacology 226 (1), 101-112. doi: 10.1007/ s00213-012-2900-0

Cedar, H., and Bergman, Y. (2009). Linking DNA methylation and histone modification: patterns and paradigms. Nat. Rev. Genet. 10 (5), 295-304. doi: $10.1038 / \operatorname{nrg} 2540$

Chen, J. H., Tsang, S. Y., Zhao, C. Y., Pun, F. W., Yu, Z. L., Mei, L. L., et al. (2009). GABRB2 in schizophrenia and bipolar disorder: disease association, gene expression and clinical correlations. Biochem. Soc. Trans. 37, 1415-1418. doi: 10.1042/Bst0371415

Chen, W. T., Huang, T. L., and Tsai, M. C. (2015). Bcl-2 associated with severity of manic symptoms in bipolar patients in a manic phase. Psychiatry Res. 225 (3), 305-308. doi: 10.1016/j.psychres.2014.12.020

Cheng, C. M., Chang, W. H., Chen, M. H., Tsai, C. F., Su, T. P., Li, C. T., et al. (2018). Co-aggregation of major psychiatric disorders in individuals with firstdegree relatives with schizophrenia: a nationwide population-based study. Mol. Psychiatry 23 (8), 1756-1763. doi: 10.1038/mp.2017.217

Christensen, J. H., Elfving, B., Muller, H. K., Fryland, T., Nyegaard, M., Corydon, T. J., et al. (2012). The Schizophrenia and Bipolar Disorder associated BRD1 gene is regulated upon chronic restraint stress. Eur. Neuropsychopharmacol. 22 (9), 651-656. doi: 10.1016/j.euroneuro.2012.01.005

Christopherson, K. S., Ullian, E. M., Stokes, C. C. A., Mullowney, C. E., Hell, J. W., Agah, A., et al. (2005). Thrombospondins are astrocyte-secreted proteins that promote CNS synaptogenesis. Cell 120 (3), 421-433. doi: 10.1016/ j.cell.2004.12.020

Chuang, D. M., Chen, R. W., Chalecka-Franaszek, E., Ren, M., Hashimoto, R., Senatorov, V., et al. (2002). Neuroprotective effects of lithium in cultured cells and animal models of diseases. Bipolar Disord. 4 (2), 129-136. doi: 10.1034/ j.1399-5618.2002.01179.x

Craig, A. M., and Kang, Y. (2007). Neurexin-neuroligin signaling in synapse development. Curr. Opin. Neurobiol. 17 (1), 43-52. doi: 10.1016/ j.conb.2007.01.011

Cross-Disorder Group of the Psychiatric Genomics, C (2013). Identification of risk loci with shared effects on five major psychiatric disorders: a genome-wide analysis. Lancet (London Engl.) 381 (9875), 1371-1379. doi: 10.1016/S01406736(12)62129- 
D’Addario, C., Dell'Osso, B., Palazzo, M. C., Benatti, B., Lietti, L., Cattaneo, E., et al. (2012). Selective DNA Methylation of BDNF Promoter in Bipolar Disorder: Differences Among Patients with BDI and BDII. Neuropsychopharmacology 37 (7), 1647-1655. doi: 10.1038/npp.2012.10

Dalva, M. B., McClelland, A. C., and Kayser, M. S. (2007). Cell adhesion molecules: signalling functions at the synapse. Nat. Rev. Neurosci. 8 (3), 206-220. doi: $10.1038 / \mathrm{nrn} 2075$

Davies, M. N., Volta, M., Pidsley, R., Lunnon, K., Dixit, A., Lovestone, S., et al. (2012). Functional annotation of the human brain methylome identifies tissuespecific epigenetic variation across brain and blood. Genome Biol. 13 (6), 1-14. doi: 10.1186/gb-2012-13-6-r43

Dell'Osso, B., D’Addario, C., Palazzo, M. C., Benatti, B., Camuri, G., Galimberti, D., et al. (2014). Epigenetic modulation of BDNF gene: differences in DNA methylation between unipolar and bipolar patients. J. Affect. Disord. 166, 330333. doi: 10.1016/j.jad.2014.05.020

Dong, E., Agis-Balboa, R. C., Simonini, M. V., Grayson, D. R., Costa, E., and Guidotti, A. (2005). Reelin and glutamic acid decarboxylase(67) promoter remodeling in an epigenetic methionine-induced mouse model of schizophrenia. Proc. Natl. Acad. Sci. U. States America 102 (35), 1257812583. doi: 10.1073/pnas.0505394102

Dong, E., Chen, Y., Gavin, D. P., Grayson, D. R., and Guidotti, A. (2010). Valproate induces DNA demethylation in nuclear extracts from adult mouse brain. Epigenetics 5 (8), 730-735. doi: 10.4161/epi.5.8.13053

du Prel, J. B., Rohrig, B., and Blettner, M. (2009). Critical appraisal of scientific articles: part 1 of a series on evaluation of scientific publications. Dtsch Arztebl Int. 106 (7), 100-105. doi: 10.3238/arztebl.2009.0100

Dwivedi, T., and Zhang, H. (2015). Lithium-induced neuroprotection is associated with epigenetic modification of specific BDNF gene promoter and altered expression of apoptotic-regulatory proteins. Front. Neurosci. 8, 1-8. doi: 10.3389/fnins.2014.00457

Dyrvig, M., Qvist, P., Lichota, J., Larsen, K., Nyegaard, M., Borglum, A. D., et al. (2017). DNA Methylation Analysis of BRD1 Promoter Regions and the Schizophrenia rs138880 Risk Allele. PloS One 12 (1), 1-19. doi: 10.1371/ journal.pone.0170121

Dyrvig, M., Mikkelsen, J. D., and Lichota, J. (2019). DNA methylation regulates CHRNA7 transcription and can be modulated by valproate. Neurosci. Lett. 704, 145-152. doi: 10.1016/j.neulet.2019.04.015

Eyal, S., Yagen, B., Sobol, E., Altschuler, Y., Shmuel, M., and Bialer, M. (2004). The activity of antiepileptic drugs as histone deacetylase inhibitors. Epilepsia 45 (7), 737-744. doi: 10.1111/j.0013-9580.2004.00104.x

Gatt, J. M., Burton, K. L. O., Williams, L. M., and Schofield, P. R. (2015). Specific and common genes implicated across major mental disorders: A review of meta-analysis studies. J. Psychiatr. Res. 60, 1-13. doi: 10.1016/ j.jpsychires.2014.09.014

Gavin, D. P., and Sharma, R. P. (2010). Histone modifications, DNA methylation, and Schizophrenia. Neurosci. Biobehav. Rev. 34 (6), 882-888. doi: 10.1016/ j.neubiorev.2009.10.010

Gavin, D. P., Kartan, S., Chase, K., Jayaraman, S., and Sharma, R. P. (2009). Histone deacetylase inhibitors and candidate gene expression: An in vivo and in vitro approach to studying chromatin remodeling in a clinical population. J. Psychiatr. Res. 43 (9), 870-876. doi: 10.1016/j.jpsychires.2008.12.006

Gawryluk, J. W., Wang, J. F., Andreazza, A. C., Shao, L., and Young, L. T. (2011). Decreased levels of glutathione, the major brain antioxidant, in post-mortem prefrontal cortex from patients with psychiatric disorders. Int. J. Neuropsychopharmacol. 14 (1), 123-130. doi: 10.1017/S1461145710000805

Geoffroy, P. A. (2018). Clock Genes and Light Signaling Alterations in Bipolar Disorder: When the Biological Clock Is Off. Biol. Psychiatry 84 (11), 775-777. doi: 10.1016/j.biopsych.2018.09.006

Goodwin, G. M., and Malhi, G. S. (2007). What is a mood stabilizer? psychol. Med. 37 (5), 609-614. doi: 10.1017/S0033291706009305

Gottlicher, M., Minucci, S., Zhu, P., Kramer, O. H., Schimpf, A., Giavara, S., et al. (2001). Valproic acid defines a novel class of HDAC inhibitors inducing differentiation of transformed cells. EMBO J. 20 (24), 6969-6978. doi: 10.1093/emboj/20.24.6969

Guidotti, A., Auta, J., Davis, J. M., Di-Giorgi-Gerevini, V., Dwivedi, Y., Grayson, D. R., et al. (2000). Decrease in reelin and glutamic acid decarboxylase67 (GAD67) expression in schizophrenia and bipolar disorder: a postmortem brain study. Arch. Gen. Psychiatry 57 (11), 1061-1069. doi: 10.1001/ archpsyc.57.11.1061

Guidotti, A., Grayson, D. R., and Caruncho, H. J. (2016). Epigenetic RELN Dysfunction in Schizophrenia and Related Neuropsychiatric Disorders. Front. Cell. Neurosci. 10, 55-60. doi: 10.3389/fncel.2016.00089

Harrison, P. J. (2015). Recent genetic findings in schizophrenia and their therapeutic relevance. J. Psychopharmacol. 29 (2), 85-96. doi: 10.1177/ 0269881114553647

Higuchi, F., Uchida, S., Yamagata, H., Otsuki, K., Hobara, T., Abe, N., et al. (2011). State-dependent changes in the expression of DNA methyltransferases in mood disorder patients. J. Psychiatr. Res. 45 (10), 1295-1300. doi: 10.1016/ j.jpsychires.2011.04.008

Hobara, T., Uchida, S., Otsuki, K., Matsubara, T., Funato, H., Matsuo, K., et al. (2010). Altered gene expression of histone deacetylases in mood disorder patients. J. Psychiatr. Res. 44 (5), 263-270. doi: 10.1016/j.jpsychires.2009.08.015

Houston, I., Peter, C. J., Mitchell, A., Straubhaar, J., Rogaev, E., and Akbarian, S. (2013). Epigenetics in the Human Brain. Neuropsychopharmacology 38 (1), 183-197. doi: 10.1038/npp.2012.78

Houtepen, L. C., van Bergen, A. H., Vinkers, C. H., and Boks, M. P. M. (2016). DNA methylation signatures of mood stabilizers and antipsychotics in bipolar disorder. Epigenomics 8 (2), 197-208. doi: 10.2217/epi.15.98

Huzayyin, A. A., Andreazza, A. C., Turecki, G., Cruceanu, C., Rouleau, G. A., Alda, M., et al. (2014). Decreased global methylation in patients with bipolar disorder who respond to lithium. Int. J. Neuropsychopharmacol. 17 (4), 561-569. doi: $10.1017 /$ S1461145713001569

Inbar-Feigenberg, M., Choufani, S., Butcher, D. T., Roifman, M., and Weksberg, R. (2013). Basic concepts of epigenetics. Fertil. Sterility 99 (3), 607-615. doi: 10.1016/j.fertnstert.2013.01.117

Kakiuchi, C., Iwamoto, K., Ishiwata, M., Bundo, M., Kasahara, T., Kusumi, I., et al. (2003). Impaired feedback regulation of XBP1 as a genetic risk factor for bipolar disorder. Nat. Genet. 35 (2), 171-175. doi: 10.1038/ng1235

Kaminsky, Z., Jones, I., Verma, R., Saleh, L., Trivedi, H., Guintivano, J., et al. (2015). DNA methylation and expression of KCNQ3 in bipolar disorder. Bipolar Disord. 17 (2), 150-159. doi: 10.1111/bdi.12230

Kao, C. Y., Hsu, Y. C., Liu, J. W., Lee, D. C., Chung, Y. F., and Chiu, I. M. (2013). The mood stabilizer valproate activates human FGF1 gene promoter through inhibiting HDAC and GSK-3 activities. J. Neurochem. 126 (1), 4-18. doi: 10.1111/jnc.12292

Kim, B., Rincon Castro, L. M., Jawed, S., and Niles, L. P. (2008). Clinically relevant concentrations of valproic acid modulate melatonin MT(1) receptor, HDAC and MeCP2 mRNA expression in C6 glioma cells. Eur. J. Pharmacol. 589 (1-3), 45-48. doi: 10.1016/j.ejphar.2008.04.058

Koch, S. M., and Ullian, E. M. (2010). Neuronal Pentraxins Mediate Silent Synapse Conversion in the Developing Visual System. J. Neurosci. 30 (15), 5404-5414. doi: 10.1523/Jneurosci.4893-09.2010

Lee, R. S., Pirooznia, M., Guintivano, J., Ly, M., Ewald, E. R., Tamashiro, K. L., et al. (2015). Search for common targets of lithium and valproic acid identifies novel epigenetic effects of lithium on the rat leptin receptor gene. Trans. Psychiatry 5 , 1-10. doi: 10.1038/tp.2015.90

Leng, Y., Liang, M. H., Ren, M., Marinova, Z., Leeds, P., and Chuang, D. M. (2008). Synergistic neuroprotective effects of lithium and valproic acid or other histone deacetylase inhibitors in neurons: Roles of glycogen synthase kinase- 3 inhibition. J. Neurosci. 28 (10), 2576-2588. doi: 10.1523/Jneurosci.5467-07.2008

Leng, Y., Fessler, E. B., and Chuang, D. M. (2013). Neuroprotective effects of the mood stabilizer lamotrigine against glutamate excitotoxicity: roles of chromatin remodelling and $\mathrm{Bcl}-2$ induction. Int. J. Neuropsychopharmacol. 16 (3), 607-620. doi: 10.1017/S1461145712000429

Leng, Y., Wang, J. Y., Wang, Z. F., Liao, H. M., Wei, M., Leeds, P., et al. (2016). Valproic Acid and Other HDAC Inhibitors Upregulate FGF21 Gene Expression and Promote Process Elongation in Glia by Inhibiting HDAC2 and 3. Int. J. Neuropsychopharmacol. 19 (8), 1-13. doi: 10.1093/ijnp/pyw035

Liu, D., Qiu, H. M., Fei, H. Z., Hu, X. Y., Xia, H. J., Wang, L. J., et al. (2014). Histone acetylation and expression of mono-aminergic transmitters synthetases involved in CUS-induced depressive rats. Exp. Biol. Med. 239 (3), 330-336. doi: 10.1177/1535370213513987

Lodge, D. J. (2013). The MAM rodent model of schizophrenia. Curr. Protoc. Neurosci. 9, 1-8. doi: 10.1002/0471142301.ns0943s63. Chapter 9, Unit9 43. 
Lopez-Leon, S., Janssens, A. C. J. W., Ladd, A. M. G. Z., Del-Favero, J., Claes, S. J., Oostra, B. A., et al. (2008). Meta-analyses of genetic studies on major depressive disorder. Mol. Psychiatry 13 (8), 772-785. doi: 10.1038/sj.mp.4002088

Ludwig, B., and Dwivedi, Y. (2016). Dissecting bipolar disorder complexity through epigenomic approach. Mol. Psychiatry 21 (11), 1490-1498. doi: $10.1038 / \mathrm{mp} .2016 .123$

Machado-Vieira, R., Ibrahim, L., and Zarate, C. A.Jr. (2011). Histone deacetylases and mood disorders: epigenetic programming in gene-environment interactions. CNS Neurosci. Ther. 17 (6), 699-704. doi: 10.1111/j.17555949.2010.00203.x

Machado-Vieira, R. (2018). Lithium, Stress, and Resilience in Bipolar Disorder: Deciphering this key homeostatic synaptic plasticity regulator. J. Affect. Disord. 233, 92-99. doi: 10.1016/j.jad.2017.12.026

Mackowiak, M., Bator, E., Latusz, J., Mordalska, P., and Wedzony, K. (2014). Prenatal MAM administration affects histone H3 methylation in postnatal life in the rat medial prefrontal cortex. Eur. Neuropsychopharmacol. 24 (2), 271289. doi: 10.1016/j.euroneuro.2013.05.013

Malhi, G. S., and Mann, J. J. (2018). Depression. Lancet 392 (10161), 2299-2312. doi: 10.1016/S0140-6736(18)31948-2

Manca, M., Pessoa, V., Myers, P., Pickles, A., Hill, J., Sharp, H., et al. (2019). Distinct chromatin structures at the monoamine oxidase-A promoter correlate with allele-specific expression in SH-SY5Y cells. Genes Brain Behav. 18 (6), e12483. doi: $10.1111 / \mathrm{gbb} .12483$

Marder, S. R., and Cannon, T. D. (2019). Schizophrenia. N. Engl. J. Med. 381 (18), 1753-1761. doi: 10.1056/NEJMra1808803

Matrisciano, F., Dong, E., Gavin, D. P., Nicoletti, F., and Guidotti, A. (2011). Activation of Group II Metabotropic Glutamate Receptors Promotes DNA Demethylation in the Mouse Brain. Mol. Pharmacol. 80 (1), 174-182. doi: 10.1124/mol.110.070896

Moon, A. L., Haan, N., Wilkinson, L. S., Thomas, K. L., and Hall, J. (2018). CACNA1C: Association With Psychiatric Disorders, Behavior, and Neurogenesis. Schizophr. Bull. 44 (5), 958-965. doi: 10.1093/schbul/sby096

Ookubo, M., Kanai, H., Aoki, H., and Yamada, N. (2013). Antidepressants and mood stabilizers effects on histone deacetylase expression in C57BL/6 mice: Brain region specific changes. J. Psychiatr. Res. 47 (9), 1204-1214. doi: 10.1016/ j.jpsychires.2013.05.028

Ouzzani, M., Hammady, H., Fedorowicz, Z., and Elmagarmid, A. (2016). Rayyan-a web and mobile app for systematic reviews. Syst. Rev. 5, 1-10. doi: 10.1186/ s13643-016-0384-4

Perisic, T., Zimmermann, N., Kirmeier, T., Asmus, M., Tuorto, F., Uhr, M., et al. (2010). Valproate and Amitriptyline Exert Common and Divergent Influences on Global and Gene Promoter-Specific Chromatin Modifications in Rat Primary Astrocytes. Neuropsychopharmacology 35 (3), 792-805. doi: $10.1038 / n p p .2009 .188$

Phiel, C. J., Zhang, F., Huang, E. Y., Guenther, M. G., Lazar, M. A., and Klein, P. S. (2001). Histone deacetylase is a direct target of valproic acid, a potent anticonvulsant, mood stabilizer, and teratogen. J. Biol. Chem. 276 (39), 36734-36741. doi: 10.1074/jbc.M101287200

Pisanu, C., Papadima, E. M., Del Zompo, M., and Squassina, A. (2018). Understanding the molecular mechanisms underlying mood stabilizer treatments in bipolar disorder: Potential involvement of epigenetics. Neurosci. Lett. 669, 24-31. doi: 10.1016/j.neulet.2016.06.045

Qiao, Y. B., Wang, R., Yang, X. F., Tang, K., and Jing, N. H. (2015). Dual Roles of Histone H3 Lysine 9 Acetylation in Human Embryonic Stem Cell Pluripotency and Neural Differentiation. J. Biol. Chem. 290 (4), 2508-2520. doi: 10.1074/ jbc.M114.603761

Reid, J. G., Gitlin, M. J., and Altshuler, L. L. (2013). Lamotrigine in Psychiatric Disorders. J. Clin. Psychiatry 74 (7), 675-684. doi: 10.4088/JCP.12r08046

Rondinelli, B., Schwerer, H., Antonini, E., Gaviraghi, M., Lupi, A., Frenquelli, M., et al. (2015). H3K4me3 demethylation by the histone demethylase KDM5C/ JARID1C promotes DNA replication origin firing. Nucleic Acids Res. 43 (5), 2560-2574. doi: 10.1093/nar/gkv090

Scaini, G., Fries, G. R., Valvassori, S. S., Zeni, C. P., Zunta-Soares, G., Berk, M., et al. (2017). Perturbations in the apoptotic pathway and mitochondrial network dynamics in peripheral blood mononuclear cells from bipolar disorder patients. Trans. Psychiatry 7, 1-10. doi: 10.1038/tp.2017.83

Schenkel, L. C., Rodenhiser, D., Siu, V., McCready, E., Ainsworth, P., and Sadikovic, B. (2017). Constitutional Epi/Genetic Conditions: Genetic,
Epigenetic, and Environmental Factors. J. Pediatr. Genet. 6 (1), 30-41. doi: 10.1055/s-0036-1593849

Schloesser, R. J., Huang, J., Klein, P. S., and Manji, H. K. (2008). Cellular plasticity cascades in the pathophysiology and treatment of bipolar disorder. Neuropsychopharmacology 33 (1), 110-133. doi: 10.1038/sj.npp.1301575

Schloesser, R. J., Martinowich, K., and Manji, H. K. (2012). Mood-stabilizing drugs: mechanisms of action. Trends Neurosci. 35 (1), 36-46. doi: 10.1016/ j.tins.2011.11.009

Seo, M. S., Scarr, E., Lai, C. Y., and Dean, B. (2014). Potential Molecular and Cellular Mechanism of Psychotropic Drugs. Clin. Psychopharmacol. Neurosci. 12 (2), 94-110. doi: 10.9758/cpn.2014.12.2.94

Serretti, A., and Mandelli, L. (2008). The genetics of bipolar disorder: genome 'hot regions,' genes, new potential candidates and future directions. Mol. Psychiatry 13 (8), 742-771. doi: 10.1038/mp.2008.29

Shahbazian, M. D., and Grunstein, M. (2007). Functions of Site-Specific Histone Acetylation and Deacetylation. Annu. Rev. Biochem. 76, 75-100. doi: 10.1146/ annurev.biochem.76.052705.162114

Shamseer, L., Moher, D., Clarke, M., Ghersi, D., Liberati, A., Petticrew, M., et al. (2015). Preferred reporting items for systematic review and meta-analysis protocols (PRISMA-P) 2015: elaboration and explanation. BMJ 350, g7647. doi: 10.1136/bmj.g7647

Stephens, S. H., Logel, J., Barton, A., Franks, A., Schultz, J., Short, M., et al. (2009). Association of the $5^{\prime}$-upstream regulatory region of the alpha7 nicotinic acetylcholine receptor subunit gene (CHRNA7) with schizophrenia. Schizophr. Res. 109 (1-3), 102-112. doi: 10.1016/j.schres.2008.12.017

Tremolizzo, L., Carboni, G., Ruzicka, W. B., Mitchell, C. P., Sugaya, I., Tueting, P., et al. (2002). An epigenetic mouse model for molecular and behavioral neuropathologies related to schizophrenia vulnerability. Proc. Natl. Acad. Sci. U. States America 99 (26), 17095-17100. doi: 10.1073/pnas.262658999

Tremolizzo, L., Doueiri, M. S., Dong, E., Grayson, D. R., Davis, J., Pinna, G., et al. (2005). Valproate corrects the schizophrenia-like epigenetic behavioral modifications induced by methionine in mice. Biol. Psychiatry 57 (5), 500509. doi: 10.1016/j.biopsych.2004.11.046

Tsai, M. C., Liou, C. W., Lin, T. K., Lin, I. M., and Huang, T. L. (2013). Bcl-2 associated with positive symptoms of schizophrenic patients in an acute phase. Psychiatry Res. 210 (3), 735-738. doi: 10.1016/j.psychres.2013.08.032

Veldic, M., Caruncho, H. J., Liu, W. S., Davis, J., Satta, R., Grayson, D. R., et al. (2004). DNA-methyltransferase 1 mRNA is selectively overexpressed in telencephalic GABAergic interneurons of schizophrenia brains. Proc. Natl. Acad. Sci. U. States America 101 (1), 348-353. doi: 10.1073/pnas.2637013100

Vieta, E., Berk, M., Schulze, T. G., Carvalho, A. F., Suppes, T., Calabrese, J. R., et al. (2018). Bipolar disorders. Nat. Rev. Dis. Primers 4, 18008. doi: 10.1038/ nrdp. 2018.8

Vigo, D., Thornicroft, G., and Atun, R. (2016). Estimating the true global burden of mental illness. Lancet Psychiatry 3 (2), 171-178. doi: 10.1016/S2215-0366 (15)00505-2

Wang, C.-C., Chen, P., Hsu, C.-W., Wu, S.-J., Lin, C.-T., and Gean, P.-W. (2012). Valproic acid mediates the synaptic excitatory/inhibitory balance through astrocytes - A preliminary study. Prog. Neuropsychopharmacol. Biol. Psychiatry 37, 111-120. doi: 10.1016/j.pnpbp.2012.01.017

Wang, L., Alachkar, A., Sanathara, N., Belluzzi, J. D., Wang, Z. W., and Civelli, O. (2015). A Methionine-Induced Animal Model of Schizophrenia: Face and Predictive Validity. Int. J. Neuropsychopharmacol. 18 (12), 1-11. doi: 10.1093/ ijnp/pyv054

Yankelevitch-Yahav, R., Franko, M., Huly, A., and Doron, R. (2015). The forced swim test as a model of depressive-like behavior. J. Vis. Exp. 97, 1-7. doi: $10.3791 / 52587$

Yatham, L. N., Kennedy, S. H., Parikh, S. V., Schaffer, A., Bond, D. J., Frey, B. N., et al. (2018). Canadian Network for Mood and Anxiety Treatments (CANMAT) and International Society for Bipolar Disorders (ISBD) 2018 guidelines for the management of patients with bipolar disorder. Bipolar Disord. 20 (2), 97-170. doi: 10.1111/bdi.12609

Zhang, C., Wu, Z. G., Hong, W., Wang, Z. W., Peng, D. H., Chen, J., et al. (2014). Influence of BCL2 gene in major depression susceptibility and antidepressant treatment outcome. J. Affect. Disord. 155, 288-294. doi: 10.1016/ j.jad.2013.11.010

Zhao, C. Y., Wang, F., Pun, F. W., Mei, L. L., Ren, L. H., Yu, Z. L., et al. (2012). Epigenetic regulation on GABRB2 isoforms expression: Developmental 
variations and disruptions in psychotic disorders. Schizophr. Res. 134 (2-3), 260-266. doi: 10.1016/j.schres.2011.11.029

Zhu, D. J., Yin, J. W., Liang, C. M., Luo, X. D., Lv, D., Dai, Z., et al. (2019). CACNA1C (rs1006737) may be a susceptibility gene for schizophrenia: An updated metaanalysis. Brain Behav. 9 (6), 1-8. doi: 10.1002/brb3.1292

Zimmermann, N., Zschocke, J., Perisic, T., Yu, S., Holsboer, F., and Rein, T. (2012). Antidepressants inhibit DNA methyltransferase 1 through reducing G9a levels. Biochem. J. 448 (1), 93-102. doi: 10.1042/bj20120674

Zong, L., Zhou, L., Hou, Y., Zhang, L. L., Jiang, W., Zhang, W. W., et al. (2017). Genetic and epigenetic regulation on the transcription of GABRB2: Genotypedependent hydroxymethylation and methylation alterations in schizophrenia. J. Psychiatr. Res. 88, 9-17. doi: 10.1016/j.jpsychires.2016.12.019

Conflict of Interest: MF's potential conflicts include previous grant support from Assurex Health, Mayo Foundation, and Medibio; consultancy from Actify
Neurotherapies, Allergan, Intra-Cellular Therapies, Inc., Janssen, Myriad, Neuralstem Inc., Takeda, and Teva Pharmaceuticals; CME/Travel/Honoraria from American Physician Institute, CME Outfitters, and Global Academy for Medical Education.

The remaining authors declare that the research was conducted in the absence of any commercial or financial relationships that could be construed as a potential conflict of interest.

Copyright (๑) 2020 Gardea-Resendez, Kucuker, Blacker, Ho, Croarkin, Frye and Veldic. This is an open-access article distributed under the terms of the Creative Commons Attribution License (CC BY). The use, distribution or reproduction in other forums is permitted, provided the original author(s) and the copyright owner(s) are credited and that the original publication in this journal is cited, in accordance with accepted academic practice. No use, distribution or reproduction is permitted which does not comply with these terms. 